\title{
Policy Instruments towards a Sustainable Waste Management
}

Göran Finnveden ${ }^{1{ }^{*}}$, Tomas Ekvall ${ }^{2}$, Yevgeniya Arushanyan ${ }^{1}$, Mattias Bisaillon ${ }^{3}$, Greger Henriksson ${ }^{1}$, Ulrika Gunnarsson Östling ${ }^{1}$, Maria Ljunggren Söderman ${ }^{2,4}$, Jenny Sahlin ${ }^{5}$, Åsa Stenmarck ${ }^{6}$, Johan Sundberg ${ }^{5}$, Jan-Olov Sundqvist ${ }^{6}$, Åsa Svenfelt ${ }^{1}$, Patrik Söderholm $^{7}$, Anna Björklund ${ }^{1}$, Ola Eriksson ${ }^{8}$, Tomas Forsfält ${ }^{9}$ and Mona Guath ${ }^{1}$

1 KTH Royal Institute of Technology, School of Architecture and Built Environment, Department of Urban Planning and Environment, Division of Environmental Strategies Research, SE-100 44 Stockholm, Sweden

2 IVL Swedish Environmental Research Institute, PO Box 530 21, SE-400 14 Stockholm, Sweden

3 Profu AB, Årstaängsvägen 1A, SE-117 43 Stockholm, Sweden

4 Chalmers University of Technology, Environmental Systems Analysis, Energy and Environment, SE-412 96 Göteborg, Sweden

5 Profu AB, Götaforsliden 13, SE-43134 Mölndal, Sweden

6 IVL Swedish Environmental Research Institute, P.O. Box 210 60, SE-100 31 Stockholm, Sweden

7 Luleå University of Technology, Economics Unit, SE-971 87 Luleå, Sweden

8 Department of Building, Energy and Environmental Engineering, Faculty of Engineering and Sustainable Development, University of Gävle, SE-800 76, Gävle, Sweden

9 Konjunkturinstitutet, P.O. Box 3116, SE-103 62 Stockholm, Sweden

* Author to whom correspondence should be addressed; E-Mail: goranfi@kth.se.

Received: 22 December 2012; in revised form: 15 February 2013 / Accepted: 18 February 2013 / Published: 27 February 2013

Abstract: The aim of this paper is to suggest and discuss policy instruments that could lead towards a more sustainable waste management. The paper is based on evaluations from a large scale multi-disciplinary Swedish research program. The evaluations focus on environmental and economic impacts as well as social acceptance. The focus is on the Swedish waste management system but the results should be relevant also for other countries. Through the assessments and lessons learned during the research program we conclude that several policy instruments can be effective and possible to implement. Particularly, we put forward the following policy instruments: "Information"; "Compulsory recycling of recyclable materials"; "Weight-based waste fee in combination 
with information and developed recycling systems"; "Mandatory labeling of products containing hazardous chemicals", "Advertisements on request only and other waste minimization measures"; and "Differentiated VAT and subsidies for some services". Compulsory recycling of recyclable materials is the policy instrument that has the largest potential for decreasing the environmental impacts with the configurations studied here. The effects of the other policy instruments studied may be more limited and they typically need to be implemented in combination in order to have more significant impacts. Furthermore, policy makers need to take into account market and international aspects when implementing new instruments. In the more long term perspective, the above set of policy instruments may also need to be complemented with more transformational policy instruments that can significantly decrease the generation of waste.

Keywords: policy instruments; landfilling; incineration; recycling; waste minimization

\section{Introduction}

The global community is facing several environmental challenges (e.g., [1,2]). Climate change, loss of biodiversity, disrupted biogeochemical cycles and use of hazardous substances are examples of environmental problems threatening a sustainable development. Fourteen out of the sixteen Swedish Environmental Quality Objectives, defining the environmental dimension of sustainable development, will not be met unless new policy measures are taken [3]. In order to develop in a more sustainable direction, all sectors of society, including waste management, need to implement measures that can lead towards a more sustainable society. The generation and management of waste depends on what activities are going on in society, and also on how these activities are controlled by public authority. In order to control the activities, decision-making bodies implement specific policy instruments, as well as issue documents, stating general policy objectives.

Responding to both economic and environmental challenges, the European Commission [1] has developed a road map for a resource efficient Europe. For waste management, the road map sets out several milestones for 2020, including:

- Waste generated per capita is in absolute decline.

- Energy recovery is limited to non-recyclable materials.

- Landfilling is virtually eliminated.

- High quality material recycling is ensured.

The waste management sector has a unique possibility of not only reducing its own environmental impacts, but it can also, through increased utilization of waste, contribute to other sectors' emission reductions. It has also been shown that an environmentally optimized waste management system can have significantly lower overall environmental impacts than the current system (e.g., [4-6]). Treatment of solid waste is surrounded by a number of rules, regulations and policy instruments. These may be quite different in different European countries [7,8] depending on traditions and contexts. The 
environmental impacts from the waste management systems are also quite different in different countries [9].

Swedish waste policy depend on a number of policy documents, including the European Union waste directive, Swedish environmental quality objectives, and policies in other sectors, including the energy sector. The European waste directive requires that the waste hierarchy should be used although exemptions can be made based on life-cycle thinking [10]. The waste hierarchy states that waste should be managed in a priority order, from prevention; to preparing for re-use; to recycling; to other recovery (e.g., energy recovery) and to the final option disposal. The Swedish environmental objective for achieving a "good built environment" states that waste disposal should be efficient for society and convenient for consumers and that waste is prevented, resources in the waste are used as much as possible while the impacts and risks for the environment and human health are minimized [11]. Waste management is also important for achieving several other environmental quality objectives including "reduced climate impact" and "a non-toxic environment" (ibid.).

Waste management in Sweden and in many other countries has undergone significant changes during the last decades. Figure 1 describes the development for household wastes indicating the clear increase in incineration and recycling and a resulting decrease in landfilling.

Figure 1. Treatment of collected municipal solid waste household waste in Sweden $[12,13]$.

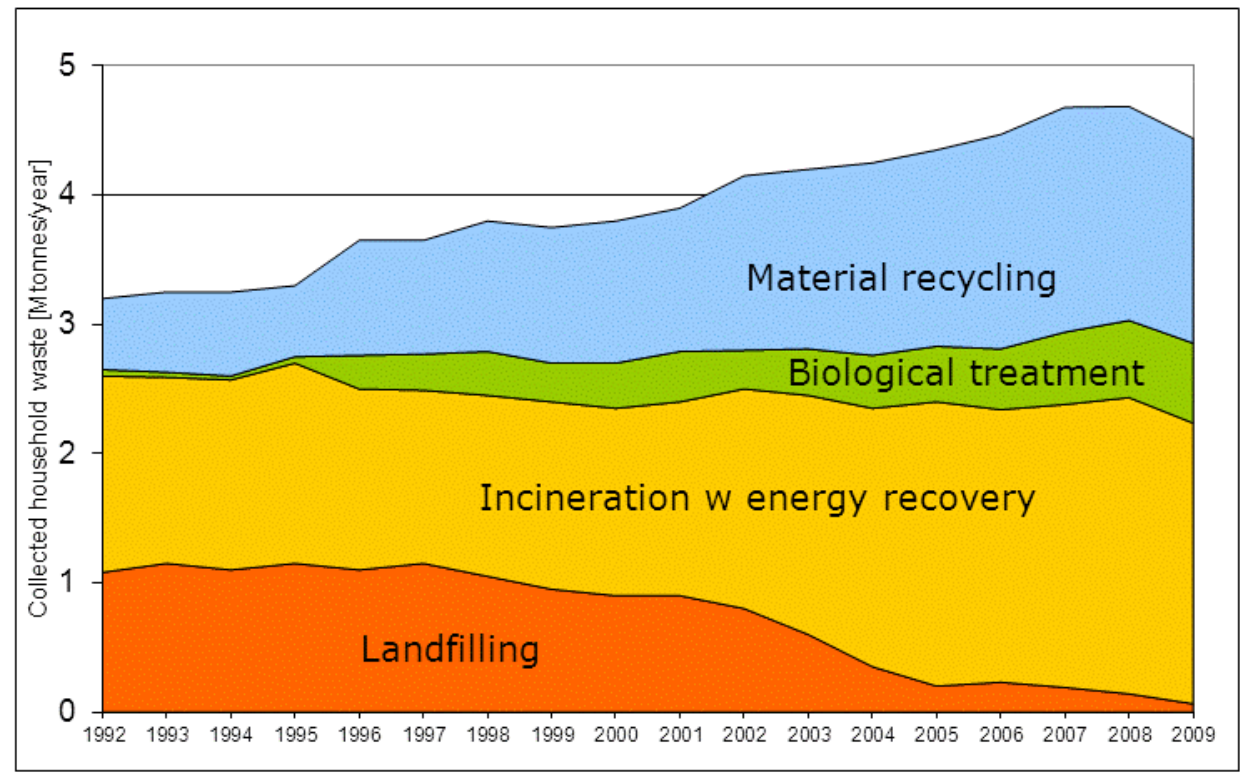

In 2010 a total of 117.6 million tons of waste were generated in Sweden. 2.5 million tons were classified as hazardous waste [14]. 4.2 million tons of total waste was the so-called secondary waste generated by waste treatment. The industrial sector of mining and quarrying (mining) accounted for 89 million tons of waste, and waste from other manufacturing industry for 7.8 million tons. The construction sector generated 9.4 million tons of waste while the infrastructure sector (energy and water supply, and sewerage and sanitation) generated 1.7 million tons. Households generated more than 4 million tons, Services generated 1.8 million tons and Agricultural industries (forestry, agricultural and fishing industries) around 310,000 tons of waste. Waste treatment generated 3.5 million tonnes of waste. 
About $80 \%$ of all waste was landfilled [14]. If mining waste is excluded, $43 \%$ of remaining waste was recycled, $28 \%$ was used as fuel, 13\% was landfilled, and $16 \%$ was disposed by land treatment or discharged to water. Recycling includes conventional material recycling (for example of paper, metals, glass and plastics), biological treatment and the use of construction materials and materials for landfill cover.

Swedish policy instruments affecting the waste management system [15] include a ban on landfill disposal of organic materials, a landfill tax and an extended producer responsibility of some product groups, including packaging waste and wastes of electrical and electronic equipment. In addition, there are also energy and carbon dioxide taxes on fossil fuels used for heating. These policy instruments have overall been effective in influencing behavior and waste management has changed.

It can be noted that most legislation operating in the field is moving waste away from landfill disposal. There are currently only a few general policy instruments that support waste prevention and increased re-use and recycling, in order to promote the higher levels of the waste hierarchy. One example is the extended producer responsibility, but it includes only a limited number of waste fractions and it does not require any recycling above the target level. To comply with the waste hierarchy there is thus a need for new policy instruments. It can also be noted that waste prevention aims not only at reducing the amounts of waste, but also at reducing the hazardousness of the waste and the environmental impacts from treatment of the waste, which suggests that policy instruments, focusing on waste prevention, should not only address waste reduction. This implies, for instance, that policy instruments in the chemicals field may have important positive impacts in this regard. Furthermore, as individual choices and socially constructed and maintained habits determine the potential for achieving sustainable waste management, policy measures promoting individuals, in households as well as in workplaces, to recycle are also needed [16,17].

The waste management system is strongly integrated in other parts of society. Thus, policies and policy instruments in other sectors will also influence the waste management. For example, waste incineration accounts for $16 \%$ of the district heating produced in Sweden [18]. All policies and policy instruments within the energy sector will therefore indirectly also influence the waste management sector. Since the energy sector is influenced by a number of policies affecting, for example, climate change, energy security and industrial competitiveness, new and existing policy instruments for the energy sector are likely to evolve.

In order to develop more sustainable waste management systems, policy instruments are needed, not the least instruments that can support the higher levels of the waste hierarchy and address the complexity of the waste management system. With the purpose to fill these policy gaps, and suggest new policy instruments for a more sustainable waste management the multi-disciplinary Swedish research program "Towards a sustainable waste management" (TOSUWAMA) was initiated by the Swedish EPA. One of the aims of the research program has been to identify and evaluate new policy instruments. The program involves nine Swedish research partners (see [19]). In the program, a more sustainable waste management system is defined as a system that contributes to increasing efficiency in the use of natural resources, and to decreasing environmental burdens. Furthermore, environmental improvements within Sweden should not be offset by unwanted consequences in other countries. To be sustainable, the waste management must also be affordable and widely accepted by the public as well as by key companies and organizations. In the program, the policy instruments intended for sustainable 
waste management have been evaluated in several parallel studies looking into economic aspects, environmental impacts and the social acceptance of the policy instruments.

The aim of this paper is to suggest and discuss policy instruments that could lead us towards a more sustainable waste management, along with proposals for further development. The paper is heavily based on evaluations from the research program, but in part it also draws from the results of other research studies. The paper is thus a synthesis of more detailed studies where specific policy instruments have been analyzed using specific methods. By making this broad synthesis we are able to draw conclusions that are not possible when more detailed studies are presented. Given the strong multi-disciplinary focus the paper does not provide a full-fledged overview of the existing literature, and/or detailed methodological descriptions. The presentation is brief emphasizing results, and the reader will need to consult the separate studies in the program for further details. The primary target group for our research is the Swedish government and authorities. For this reason, the primary focus of the assessment is on policy instruments that the Swedish government and authorities can decide on, in other words on a separate, Swedish implementation of the instruments. However, a broader geographical scope is also relevant, since Swedish authorities can choose to strive for the implementation of some of the policy instruments on, for example, the EU level. Although not our primary target group, most of the content in this paper should also be relevant for policy makers in other industrialized countries around the world.

\section{Methods}

\subsection{Introduction}

This paper synthesizes and draws conclusions from several empirical studies made within the TOSUWAMA research program. These assessments are published in other reports and papers, which are used as references in this publication. Besides results from the program, also other relevant results are referred to in the discussion.

Bisaillon et al. [20] and Finnveden et al. [21] presented an inventory of a large number of policy instruments suggested by stakeholders and in the literature. Based on this inventory they identified 16 instruments as interesting candidates deserving further evaluation. This identification was based on the results from a workshop with stakeholders but also criteria developed within the program. The criteria for choosing the interesting candidates included environmental and economic impacts and social acceptability, but also program-specific criteria such as novelty and research interest. In the research program 13 of the 16 policy instruments (Table 1) have been assessed from three main perspectives: economic impacts, environmental impacts and social acceptance. In addition, a futures perspective was taken. Specifically, each type of assessment was made with reference to different possible future developments, illustrated in five external scenarios for the year 2030 [22,23]. These scenarios are:

0: Reference scenario, assuming developments in accordance with official forecasts made in 2008

1: Global sustainability, assuming globalization and strong political control over the environment and natural resources. 
2: Global markets, assuming globalization and weak political control over the environment and natural resources.

3: Regional markets, assuming regionalization and weak political control over the environment and natural resources.

4: European sustainability, assuming regionalization and strong political control over the environment and natural resources.

Table 1. Assessment of policy instruments in the research program TOSUWAMA.

\begin{tabular}{lccc}
\hline Policy instrument & $\begin{array}{c}\text { Economic } \\
\text { assessment }\end{array}$ & $\begin{array}{c}\text { Environmental } \\
\text { assessment }\end{array}$ & $\begin{array}{c}\text { Assessment of } \\
\text { social acceptance }\end{array}$ \\
\hline Climate tax on waste incineration & $\mathrm{X}$ & $\mathrm{X}$ & \\
Including waste in the green certificate system & $\mathrm{X}$ & $\mathrm{X}$ & \\
for electricity production & $\mathrm{X})$ & $(\mathrm{X})$ & \\
$\begin{array}{l}\text { Compulsory recycling of recyclable materials } \\
\text { Tradable Recycling Credits }\end{array}$ & $\mathrm{X}$ & $\mathrm{X})$ & \\
Weight-based tax on incineration of waste & $(\mathrm{X})$ & $\mathrm{X}$ & $\mathrm{X}$ \\
Weight-based waste collection fee & $\mathrm{X}$ & $\mathrm{X}$ & $\mathrm{X}$ \\
$\begin{array}{l}\text { Developed recycling systems } \\
\text { Tax on virgin raw materials }\end{array}$ & $\mathrm{X}$ & $\mathrm{X}$ & $\mathrm{X}$ \\
$\begin{array}{l}\text { Advertisements on request only } \\
\text { Differentiated VAT }\end{array}$ & $\mathrm{X}$ & $\mathrm{X}$ & $\mathrm{X}$ \\
$\begin{array}{l}\text { Environmentally differentiated waste fee } \\
\text { Information to household and enterprises }\end{array}$ & & & $\mathrm{X}$ \\
Mandatory labeling of goods containing & & & $\mathrm{X}$ \\
hazardous substances & & & \\
\hline
\end{tabular}

(X) indicates that the evaluations are based on previous studies.

Results from the evaluations of the policy instruments in Table 1 are presented in Section 3. In the discussion in Section 4 also other policy instruments (e.g., other instruments identified by [20]) are included.

\subsection{Integrated Approach for Quantitative Analysis}

Several methods and scientific disciplines have been applied in the assessment of policy instruments within the research program TOSUWAMA. For the quantitative analysis, three existing quantitative tools have been combined and refined in order to assess economic and environmental aspects $[24,25]$ :

- The Environmental Medium term Economic model (EMEC) is a computable general equilibrium (CGE) model of the Swedish economy [26]. The EMEC model has been extended in order to analyze the relation between economic activity and waste generation. Data on waste quantities has been compiled and assigned to different economic activities and different sectors [23]. In the model, the waste generation of households and firms depend on their respective economic activities and is sensitive to changes in the price of goods and services. The waste-management costs are assumed to 
affect the total cost of utilizing goods and services. Hence, households and firms incorporate waste-management performance into their decisions [24]. The waste generation is directly or indirectly influenced by changes in government policies, e.g., tax policies [27].

- NatWaste is a systems engineering model of the Swedish waste management system $[28,29]$. Based on cost optimization, NatWaste calculates the cost-effective mix of technologies for managing Swedish waste. The cost-effective mix is the set of technologies that gives the lowest total economic costs (excluding external environmental costs and private consumers' time) on the basis of the conditions defined for the analysis. Among the most influencing conditions are the choice of treatment technologies defined for each waste type (including their unit costs and performance) as well as the scenarios.

- Swedish Waste management Environmental Assessment (SWEA) is a life cycle assessment (LCA) model of the Swedish waste-management system [30]. LCA is a tool for assessing the potential environmental impacts of a product or a service (e.g., [31]), in this case waste management. Since a life-cycle perspective is used, credit is given to useful products, materials and energy carriers produced in the waste-management system that can replace products produced from virgin raw materials, in line with established LCA methodology for waste management (e.g., [32,33]). In addition, SWEA includes the reductions in material production of material that follows from waste-prevention efforts. This allows the model to account for the environmental benefits of waste prevention. SWEA has been implemented in the Simapro software [34] and for Life Cycle Impact Assessment the Recipe methodology [35] was used together with Cumulative energy demand [36] and Cumulative exergy demand [37].

The three models feed each other with information (Figure 2). EMEC and NatWaste are soft-linked in the sense that some variables solved for in one model are transferred into the data set of the other model in an iterative process. The last step is to feed the cost-effective mix of waste management technologies as calculated by NatWaste into SWEA for analyzing the life cycle environmental impacts. The linking of these three models allows us to consider how policy instruments intended to prevent waste generation or direct waste management in a more sustainable direction could affect: (1) the macroeconomic development, such as GDP growth and structural changes in the economy as a whole, (2) the cost-effective mix of technologies for managing Swedish waste and (3) the resulting life cycle environmental impacts. Furthermore, the approach makes it possible to capture if and how waste-management costs affect waste generation [25].

One advantage of this integrated modeling approach is that it enables a broad analysis. A general equilibrium model covers the whole economy in a geographical area, and can thus address important interactions between different sectors in the economy in a consistent manner. NatWaste calculates net costs for managing many of the environmentally relevant waste streams generated in Sweden and adds the technological detail needed to investigate specific technology choices in waste management. NatWaste also includes costs and revenues generated by waste management linked to energy and material production systems. An LCA model like SWEA covers the waste-management system and the 
energy and materials production systems that are affected by the waste management. This is essential since the environmental consequences of waste management often depend more on the impacts on surrounding systems than on the emissions from the waste management system itself [38].

Figure 2. Combination of models for assessing policy instruments for sustainable waste management [25].

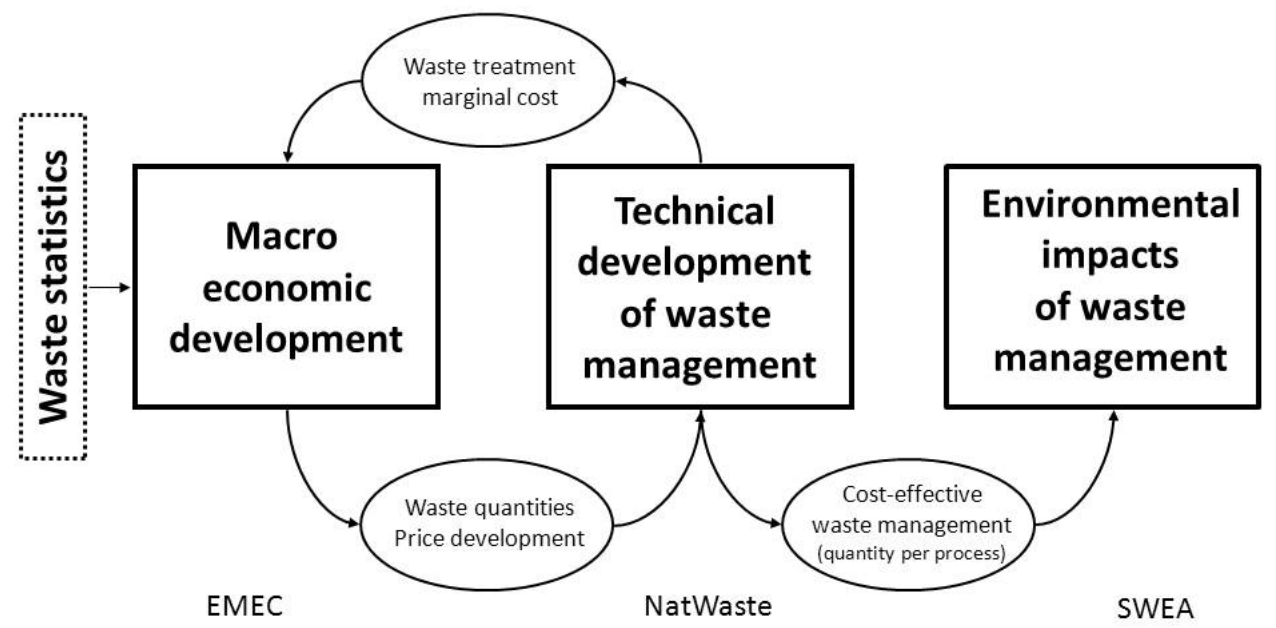

However, any model is always a simplification of reality. Optimizing models such as EMEC and Natwaste assumes perfect knowledge about future costs and economic rational behavior from actors. LCA models calculate potential (and not actual) environmental impacts. Furthermore, in any modeling activity there is a trade-off between scope and detail [39], which means that the broader the scope of a model, the more aggregated (and thus generalized), the level of the analysis. In addition to the results from these three models, we have also relied on other modeling approaches in the evaluation of the proposed policy instruments. These include different economically optimizing models (e.g., [40]) as well as life cycle assessment models that are further described below. A number of econometric analyses have also been conducted to investigate the behavior of recycling markets, e.g., to estimate how the supply of recycled materials is affected by price changes (e.g., [41]).

\subsection{Qualitative Assessment}

In addition to the quantitative models, we have applied qualitative analyses [42] and also methods from culture analysis and psychology [43-45]. This provides a context-based understanding of policy impacts, and thus complements the quantitative results.

Ethnographic methodology - fieldwork, qualitative interviews and observations - has been used to collect data on how waste policy instruments implemented since the 1990s have been received in the context of households and workplaces. Culture analysis as a method for analyzing ethnographic data (see, e.g., [46]) has been applied in order to find out how existing policy instruments, i.e., current waste handling conditions in everyday life, are anticipated, accepted, and acted upon. Issues analyzed include in what ways policy measures are based upon general cultural understandings concerning, for example, protection of the environment and also how different actors (e.g., municipalities) are seen as (economically, politically and morally) responsible for taking care of waste. Furthermore, we have 
analyzed whether waste legislation, as it is operating in everyday life contexts, has been perceived legitimate, and comprehensible (i.e., possible to understand in a meaningful way).

The qualitative evaluation of a handful of suggested (not yet implemented) waste policy instruments has been based on a combined approach of ethnology and psychology. The method for this qualitative ex-ante evaluation of new policy instruments was developed as part of the program [45]. It included several group discussions within the project team, one of them also including external laymen and stakeholders. The resulting evaluation was thus based on reasoning concerning whether each of the instruments were in line with cultural patterns and also psychological parameters. In practice the evaluation entailed the following analytical categories:

(i) if the instrument matched the individual's / household's environmental commitment;

(ii) the perceived social fairness of the instrument;

(iii) if the policy instrument would affect the individuals or households directly or indirectly (i.e., through other stakeholders, such as landlords);

(iv) how the policy instruments would interact, or be in conflict, with fundamental cultural categories and practices [43];

(v) if the instrument would conform or not with the users' general understanding [47] of the waste system's task and function (e.g., to be a community service that minimizes environmental impact), and

(vi) the (un)certainty of the message conveyed through the policy instrument (uncertainty regarding environmental impact; the benefit of oneself doing something and uncertainty about what others are doing, i.e., social uncertainty).

Based on the methodology outlined, Andersson et al. [44] produced a summary for each instrument assessed, concerning how well it would function from a combined ethnological and psychological perspective. This study presented conclusions as to whether the policy instrument was considered socially and culturally anticipated and acceptable, and gave recommendations on how it could be modified to better achieve its purpose.

The qualitative research in TOSUWAMA also involves a stakeholder analysis [48] and a comparative static analysis of the impacts of developed recycling systems, tradable recycling credits and virgin materials taxes [49]. Such qualitative research is important as it explicitly addresses the key characteristics of different policy instruments (e.g., the incentives provided by a tax), and not only the impacts of specific policy proposals (e.g., a tax of $\mathrm{x}$ SEK $/ \mathrm{kg}$ ). This is also complemented by drawing on the practical experiences of policy instruments in the past and in other countries (e.g., [50]).

In sum, the emphasis on multi-disciplinary research efforts and the combination of quantitative and qualitative approaches, imply that a holistic approach to policy instrument evaluation is employed. In the following the most important insights and results from the program are outlined.

\section{Evaluation of Policy Instruments}

In the following, each of the evaluated policy instruments is described in terms of design and assumptions about its (hypothetical) implementation, along with results from the qualitative and quantitative assessments. Table 1 gives an overview of what type of assessments were done for each 
policy instrument as part of the projects within this research program. These assessments are complemented with findings from a number of related research projects (although no complete overview of the existing literature is provided).

\subsection{Climate Tax on Waste Incineration}

\subsubsection{Description and Assumptions}

This policy instrument is a tax on fossil $\mathrm{CO}_{2}$ emissions generated from waste incineration. In the analyses, the level of the tax is assumed to be $0.95 \mathrm{SEK} / \mathrm{kg} \mathrm{CO}$ for waste incineration plants with district heat production only (DHO) and $0.15 \mathrm{SEK} / \mathrm{kg} \mathrm{CO}_{2}$ for waste incineration plants with combined heat and power production (CHP) (1 SEK corresponds to about 0,11 EUR and 0.15 USD, respectively in February 2013). The differentiation of the tax level is a result of the Swedish energy taxation system with the aim of increasing combined heat and power production and it is further described by Bisaillon et al. [20]. The proposed policy instrument would imply that $\mathrm{CO}_{2}$ from fossil sources in the waste is taxed in the same way as fossil fuels in general.

Most of the fossil $\mathrm{CO}_{2}$ emissions originate from plastic waste. The evaluated tax levels correspond to $2900 \mathrm{SEK} /$ ton plastic waste at DHO plants and $450 \mathrm{SEK} /$ ton plastic waste at CHP plants [29]. By making waste incineration a more expensive option, the idea of the tax is to make recycling of plastic waste (and other material with fossil origin) an economically more favorable option.

\subsubsection{Results of the Evaluation}

The climate tax adds to the costs of the waste-management system. However, the cost-optimizing mix of treatment technologies in the NatWaste model for the year 2030 is not affected by the tax [29]. For the waste fractions where the model can choose between waste incineration and recycling, waste incineration is the cost-efficient technology even with the tax. Note, however, that the optimum mix of technologies in the year 2030 includes no waste incineration with DHO. All incineration has CHP, which means that only the lower tax level is used.

The investigated tax might, however, have some effect in the current system, because some incineration plants today have DHO and would be affected by the higher level of the tax. In addition, NatWaste includes only two average costs for recycling of plastics (from households and industries respectively). Sahlin et al. [40] evaluated the climate tax with a spread-sheet model that included estimated marginal-cost curves for increased rates of recycling of plastic waste from households. This was an attempt to take into account local variations and also variations in the reluctance of households to increase source separation. The results indicate that the climate tax in the current system would increase the recycling of Swedish hard plastics packaging from households by $14 \%$, corresponding to an annual amount of 4 ktonne. Ekvall et al. [48] argue that the effect on the source separation in households in reality might be much smaller, because the climate tax affects the households indirectly only. On the other hand, the tax can contribute to stimulating recycling of materials other than plastics through increased gate fees at waste incinerators or through improved collection systems in general. All this implies that the tax might have some short-term effects on the recycling rate of waste with fossil origin. 
The analysis with the NatWaste model is limited to the treatment of Swedish waste. It does not include effects on imports of waste to Swedish incineration plants, an import that has grown in recent years and currently accounts for $15-20 \%$ of the total waste incinerated. A climate tax could lead to higher gate fees at waste incineration which in turn, according to Olofsson et al. [51], could reduce the drivers for import of any waste for incineration in Sweden. This could contribute to increasing landfilling, incineration, biological treatment, and/or recycling of various kinds of waste in other countries [48]. However, the tax level required for shifting the cost-effective technology for imported waste has not been analyzed.

All in all, the model results and our analysis indicate that a climate tax on waste incineration in line with the current $\mathrm{CO}_{2}$ taxation could have a very modest effect on the future waste management system and consequently, the resulting environmental impacts would also be limited.

\subsection{Including Waste in Green Certificates for Electricity Production}

\subsubsection{Description and Assumptions}

In the existing system of green certificates for electricity production in Sweden, electricity producers who use renewable sources get certificates from the government. All electricity suppliers are required to have a certain quota of certificates. The suppliers that do not get them by their own production can buy them from other producers. The aim of the system is to increase the production of electricity from renewable sources. The system is further described by Bisaillon et al. [20] and by Bergek and Jacobsson [52].

Currently, electricity production from mixed renewable waste is not included in the system so almost no certificates are given for electricity production from waste incineration. Only the electricity production generated from combustion of separated wood fractions at the incineration plants are included in the current system. In the research program, the following policy change has been studied: certificates are given for the whole mixed fraction of the waste that comes from renewable sources, such as food waste, wood, cardboard etc. but not for the fractions of non-renewables such as fossilbased plastics. The idea of this policy is to stimulate CHP in waste incineration. In the analysis, the price of a green certificate is assumed to be $200 \mathrm{SEK} / \mathrm{MWh}$.

\subsubsection{Results of the Evaluation}

Expanding the system of green certificates to waste incineration will reduce the total net cost of the waste-management system. However, the cost-optimizing mix of treatment technologies in the NatWaste model is unaffected in most scenarios for the year 2030 [29]. The exception is Scenario 2, where the certificate system means that some organic waste fractions are treated by waste incineration instead of anaerobic digestion. The waste incineration increases from 12,820 ktonne (without the policy instrument) to 12,906 ktonne (with the instrument implemented). Electricity production increases slightly, and biogas generation decreases. All this leads to slight changes in the environmental impacts of the system [30]. 
The modest impact is by large explained by the fact that all waste incineration is CHP in 2030 even without the policy instrument, according to the NatWaste results. The extra incentive provided by the certificates therefore has a limited impact in the year 2030 .

\subsection{Compulsory Recycling of Recyclable Materials}

\subsubsection{Description and Assumptions}

Although recycling has increased in Sweden, recyclable materials are still being incinerated $[5,53]$. One policy proposal is therefore to introduce compulsory recycling of recyclable materials, except for materials where incineration leads to lower life cycle environmental impacts. Examples of such materials could be wood waste, yard waste and some types of sludge. A more precise description of the instrument could therefore be Compulsory recycling of materials defined as recyclable.

Although this policy proposal is fairly new to the Swedish context, similar policies exist in several places in North America. For instance, in the State of Massachusetts, a ban on incineration and landfill disposal of some recyclable products was introduced in 1990 [54]. The material is only banned from incineration if there are alternative market outlets available. This definition is revised on a continuous basis. Moreover, in the State of Vermont recycling of organic waste will be required [55], and the city of Vancouver has banned disposal of a number of materials including recyclable paper and some containers [56].

\subsubsection{Results of the Evaluation}

Ambell et al. [4] analyzed the cost and environmental impacts of maximizing materials recycling, using the models NatWaste and SWEA. Food waste and other organic waste fractions were not included in this evaluation. In the reference scenario for 2030, the following additional quantities of materials are assumed to be recycled.

- Paper: 1386 ktonne (+90\%)

- Metals: 263 ktonne (+14\%)

- Plastics: 980 ktonne (+398\%)

- $\quad$ Glass: 91 ktonne $(+26 \%)$

- $\quad$ Rubber: 63 ktonne (+394\%)

- Gypsum: 615 ktonne (+81\%)

- Textiles: 205 ktonne (+801\%)

These calculations are based on maximum material recovery, meaning all recyclable materials in mixed waste fractions were assumed to be source separated and recycled. A major challenge with this instrument is to decide what material can be recycled. What quantities would be affected in reality depends on the details of the regulations, e.g., on how the concept of recyclable materials is defined, and on practical limitations concerning what can actually be source separated. The SWEA results indicate that introducing a requirement to recycle recyclable materials would lead to significant reductions for the analyzed impact categories: global warming potential, photochemical oxidant formation, terrestrial acidification, freshwater eutrophication, marine eutrophication, and total energy use. 
The environmental benefits were valued using the economic valuation method EcoValue 08 [57] showing decreased environmental cost of 1 or 250 billion SEK depending on whether the low or high valuation set is used [58]. It can be noted that all relevant environmental impacts, such as human and eco-toxicological impacts, were not included in the study by Ambell et al. [4] implying that the environmental benefits could be underestimated.

The economic optimization using NatWaste indicates that, compared to the reference case, maximizing recycling increases the overall waste management system cost by 10 billion SEK [4]. This corresponds to an average cost of $3800 \mathrm{SEK} /$ ton of extra waste recycled. This cost is especially sensitive to the data and assumptions regarding plastic waste recycling. In a sensitivity analysis, where the costs of plastic waste recycling is reduced by $33 \%$, the average cost of the obligation decreases to $2400 \mathrm{SEK} /$ ton of extra waste recycled (corresponding to 7 billion SEK). As a comparison, the marginal cost for collection and recycling of plastic packaging has been estimated to be in the order of 4,000 SEK/ton [59]. This marginal running cost is valid for increased collection and recycling of plastic packaging waste in the range of additionally $10-20 \%$ of the current collected amounts.

Ambell et al. [4] used constant average unit costs for each fraction, i.e. unit costs did not increase with recycled quantities. It can be expected that in a given time period the recycling cost per ton will increase with higher quantities of materials being separated. On the other hand, the Ambell study does not include any possible future cost reductions from technological developments and from using large scale solutions which may lead to economies of scale and decreased costs with higher recycling rates. The costs of recycling may thus both increase and decrease with increased recycling.

Bernstad et al. [5] did a study which in some aspects is similar to the study by Ambell et al. [4] using the Danish LCA-model EASEWASTE applying it to a residential area in Southern Sweden. They also found that there is a potential for increased recycling and that if this potential is realized, the environmental impacts analyzed would decrease.

Ambell et al. [4] did not take into consideration that compulsory recycling of recyclable materials could contribute to changes in the waste management in other countries. Such effects can be environmentally important and depend on the details of the policy instrument. As discussed above, 15\% (about 0.8 million tons) of the waste incinerated in Sweden comprises imported European waste [60], of which the majority, in the short-term, probably would have been directed to landfills abroad. This is valid as long as landfill disposal is the dominating treatment method in the exporting countries. In the coming years, the imports are expected to double [60]. The future import of waste is however very uncertain and depend e.g. on waste policies in the exporting countries. This policy instrument would stop import of recyclable waste to Sweden and possibly, in the short-term, increase landfilling, and, in the long-term, if the European policy of "virtually eliminating landfilling" as referred to in the introduction comes into effect, increase recycling in other European countries. The ban in Massachusetts resulted in some waste being exported to neighboring states for incineration and landfill disposal $[54,61]$.

The social acceptance of this policy instrument was not studied explicitly. However, it seems reasonable that some stakeholders, e.g., waste and energy companies will oppose since it would reduce the quantity of waste available for incineration. Since this policy instrument would require efficient waste separation, at source, after collection or both, high social acceptance is needed for a successful implementation. 


\subsection{Tradable-Recycling-Credits}

\subsubsection{Description and Assumptions}

Systems for tradable recycling credits can be designed in different ways. The following version is evaluated within this research program: a minimum recycling level (quota) or rate for a particular material is imposed. To make this happen so-called recycling credits are awarded to the company that use recycled material in the production of new products. The manufacturers of the products containing the material would be required to meet a specific share of recycled material. They could perform the recycling themselves or they could purchase credits from others who have recycled more than their own obligation. A similar system exists in the UK since 1997, and it is known as the Packaging Recovery Notes (PRN) [62,63].

The evaluation of this type of policy instrument is primarily based on relatively simple comparative static models [49], but this is complemented by empirical evidence on the behavior of key secondary material markets such as steel scrap, secondary aluminum, wastepaper etc. (e.g. [41,64]). The specific impacts of tradable recycling credit schemes are likely to be highly context-specific, and thus deserve increased attention in future research.

\subsubsection{Results of the Evaluation}

The impact of this system depends on whether an established market for recyclables exists for the material. It also depends on the geographical scope of the system. A national Swedish system for tradable recycling credits can be ineffective in the case of materials for which an international market for recyclables exists (e.g., metals and paper). There is a risk that although a larger share of the material collected for recycling will be used in Sweden, it may simply increase imports and thus have little or no effect on the total (global) recycling of the material unless the instrument is combined with explicit supply-side policy measures (e.g., waste sorting and collection). Similar trade-related issues have been a concern in the UK system [62]. Important interactions with other policy instruments also need to be addressed. For instance, Matsueda and Nagase [63] show, in the context of the UK scheme, that introducing a tradable recycling credit scheme together with a higher tax at the landfill could in fact raises the amount of landfill waste.

An international system for tradable recycling credits could be more effective. A national system can also work for materials that are mainly traded within Sweden (e.g., glass and gravel). When the system has the same geographical scope as the market, the market impacts of this policy can be described as follows [49]. The implementation of the quota leads to an increased supply of recycled material, and a corresponding fall in the use of virgin material (given a fixed total demand for the material). The price faced by virgin material suppliers will therefore fall. In order for the quota obligation to be fulfilled the suppliers of secondary materials will receive extra revenue per unit material supplied. The producers of material-containing products can in turn finance their purchases of recycling credits by levying an extra fee on end consumers.

The conclusion is that a tradable recycling credit scheme has a potential environmental gain, at least when the geographical scope of the system is at least as large as the geographical scope of the market. With a well-functioning market for certificates or credits (i.e., many actors, low transaction costs etc.), 
cost-efficient solutions for recycling are sought. This means that a given recycling level can be achieved at minimum cost.

However, when the supplied quantity of secondary, recycled material is forced to increase, the cost to achieve the goal will be uncertain. The scheme will increase the price of secondary materials, but the supply of secondary materials is typically not very sensitive to changes in the price (e.g., [41]). This means that the price of the material and, hence of the recycling credits, might have to be very high to reach the target level of recycling. The cost is also expected to rise steeply if the target is increased, e.g., if the practical difficulties in the recycling process have been underestimated. Still, the environmental benefits of increased recycling are not likely to rise steeply in a similar way. For this reason, it can be argued that the economic efficiency of introducing this type of quantity-setting measure may be low (based on Weitzman's [65] seminal studies on the choice between price- versus quantity-based policies). It might instead be more efficient to stimulate recycling through the use of price-based policy instruments (e.g., virgin material taxes; see, however, Section 3.8).

The risks for high compliance costs can be alleviated if the system of tradable recycling credit is combined with measures to increase the collection of used materials for recycling. Exceedingly high costs can be completely avoided by allowing producers to stay outside the system for a fixed fee per ton of material. This fee will then set a ceiling for the price of recycling certificates. In a well-functioning market for certificates, the companies have the freedom to choose and flexibility to develop and search solutions for cost-efficient recycling. This would probably have a positive influence also on the producers' acceptance for such a system.

On the other hand, this kind of system could also neutralize the effect of voluntary efforts to increase recycling levels. This is because the quota puts a cap on the amount of recycling, and voluntary initiatives will not add to this cap; instead they will simply make it easier and thus cheaper for product manufacturers to comply with the cap. From the perspective of the "volunteers" (e.g., consumers with strong preferences for recycled products), the acceptance can therefore be low.

\subsection{Weight-based Tax on Incineration of Waste}

\subsubsection{Description and Assumptions}

This policy instrument is a weight-based tax on incineration of solid waste. Incineration of waste from both renewable and non-renewable materials would be taxed. Different versions of the tax could be implemented. The tax could be introduced for only household waste or for all types of waste. The tax could also be introduced with a tax reduction for plants with combined heat and power production.

Slightly different versions of taxes on incineration of waste have been evaluated. Björklund and Finnveden [66] studied the environmental impacts using an LCA model of a tax of $400 \mathrm{SEK} / \mathrm{ton}$ on incineration of household waste without tax reduction for CHP. Sahlin et al. [40] studied the incineration tax that was implemented in Sweden from the year 2007 to 2010 and compared it to the net marginal costs of waste treatment alternatives. This tax was slightly higher than $400 \mathrm{SEK} /$ ton for household waste in DHO, but much lower for CHP. This construction aimed to stimulate CHP and also to mimic the tax on fossil fuel used in the Swedish district-heating sector based on average contents of fossil material in municipal solid waste. In both cases the tax was assumed to have an impact on the 
gate fee for waste incineration. This makes waste incineration less economically competitive in general compared to alternative treatment such as material recycling and biological treatment.

\subsubsection{Results of the Evaluation}

Increased gate fees will affect all actors that deliver household waste at the incineration plant; waste collection companies and similar. Their cost increase is likely to be transferred to the households and the companies, and increase their cost for waste treatment.

The proposed design of the tax is expected to increase recycling only to a small extent, and give rise to small environmental improvements and energy savings [40,66]. Using an optimizing spreadsheet model (cf. Section 3.1.2), Sahlin et al. [40] predicted the largest effect on household waste to be on biological treatment of kitchen and garden waste, which would increase from 16 to $17 \%$ (level of 2006) out of the total treatment of household waste. Ekvall et al. [48] argue that even this modest result might be an overestimate. In order to have an effect on the treatment of household waste, the tax must affect the source separation in households, and an incineration tax affects the households only indirectly.

If the tax includes a reduction for CHP, waste may be redirected to CHP plants from heat-only boilers. This is expected to give further environmental improvements, at least in the short-term when not all waste incineration has CHP. On the other hand, the tax reduction will of course also lower the economic incentive for finding alternative waste treatment methods.

Concerning the acceptability of this policy instrument it can be noted that the waste incineration tax that was introduced in 2007 met strong resistance from several stakeholders including the municipal waste management companies although it had support from other stakeholders, including recycling companies [67]. After a general election and change of government, the tax was eventually removed, also indicating different political opinions concerning the tax.

\subsection{Weight-based Waste Collection Fee}

\subsubsection{Description and Assumptions}

The idea of a weight-based fee is that the households pay per mass of waste discarded. The weight-based waste collection fee can have an effect in two ways:

- an economic incentive to reduce the quantity of residual waste though prevention, recycling, or irregular or illegal waste treatment, and

- raised attention to waste-management issues that, at least temporarily, can result in waste prevention and increased recycling.

Bisaillon et al. [20] propose to assess a waste collection fee for households with a fixed part (850 $\mathrm{SEK} /$ household and year) and a variable part (2.12 $\mathrm{SEK} / \mathrm{kg}$ residual waste). Based on earlier studies $[68,69]$ it is assumed that this leads to a $20 \%$ reduction of the collected residual waste. Since there are several plausible explanations to the reduction we have analyzed three extreme alternatives $[29,48]$ : 
1. All reduction in residual waste is due to prevention of waste with the same composition as the average residual waste.

2. All reduction in residual waste is due to an increase in source separation for home composting (50\%) and materials recycling (50\%).

3. All reduction in residual waste is due to illegal treatment: e.g. burning of combustible waste in private stoves or dumping of food and garden waste in the forest.

\subsubsection{Results of the Evaluation}

From an environmental perspective, the fate of the waste that is not collected as mixed residual waste is important. Arushanyan et al. [30] show that Alternatives 1 and 2 could lead to environmental benefits. The waste prevention in Alternative 1 could reduce greenhouse gas (GHG) emissions in the year 2030 by 2300 kton $\mathrm{CO}_{2}$-eq. Using two versions of the Ecovalue method, Arushanyan et al. [30] calculated the total environmental benefit from the policy instrument to correspond to 1 or 128 billion SEK for the two sets of values in the method.

The increased recycling in Alternative 2 could reduce GHG emissions by 600 kton $\mathrm{CO}_{2}$-eq. The total environmental benefit was calculated to 0.2 or 1.3 billion SEK [30].

The environmental impacts of Alternative 3 were not evaluated in this study. However it is clear from previous studies that uncontrolled burning of waste can lead to significant emissions of hazardous compounds [70]. Therefore emissions from uncontrolled burning can be significant compared to the total emissions, even if the amount combusted in uncontrolled burning is just a fraction of a percent (ibid).

The risk of increased uncontrolled burning and other illegal treatment is lower when the households are driven by strong pro-environmental attitudes, and higher when they are simply interested in the impacts on the household budget. After deep-interviewing 42 households in Gothenburg, where the fee was recently introduced, Schmidt et al. [71] concluded that the main driver for change is not the fee as such since it is small compared to the total household budget. Instead, the households seem to be affected mainly by the norm-activating information that was distributed as the fee was introduced and by the regular feedback from the system, which both confirm the feeling that "sorting is doing the right thing". This is also in line with the results of Sterner and Bartelings [72] that economic incentives are not the only driving force behind a reduction in waste. This implies that the increase in uncontrolled burning could be small.

The consequences in the year 2030 depend on how the society and associated norms develops in the future. Ekvall et al. [48] argue that the weight-based waste fee can be expected to have good environmental consequences in scenarios where the environmental awareness is great (Scenarios 1 and 4; [22]). In scenarios where private economic impacts are among the dominating driving forces (Scenarios 2 and 3), the risk of a significant increase in illegal treatment is greater. Fullerton and Kinnaman [73] as well as Walls and Palmer [74] show that if illegal dumping behavior is present a combined output tax and recycling subsidy could be an efficient second-best policy. The tax discourages production of waste-intensive products, while the subsidy encourages substitution of secondary materials for virgin materials.

The connection between external scenarios and the effect of a weight-based fee might, however, be more complex than this. Andersson et al. [44] suggest that the policy instrument, since it is a market-based 
instrument, will most likely function well in market-oriented scenarios (Scenarios 2 and 3) where the individual takes a large responsibility, and that it will not be as effective in the "sustainabilityscenarios" (Scenarios 1 and 4) where sustainability is a natural part of the society.

A weight-based fee requires technological and administrative systems: trucks with scales, etc. The associated costs are likely to differ across regions, thus suggesting that it should not be implemented uniformly across the entire country. It is in general well accepted by the households [71]. An exception might be households with seemingly unavoidable large volumes of residual waste [44,71], for example families with children in diapers.

The legitimacy of a weight-based waste collection fee might, however, decline over time due to, for example, distrust in the system or if the recycling stations are not emptied often enough to absorb the increased flow of source-separated materials. In order to have beneficial long-term effects the fee should be complemented with increased collection frequency at recycling stations and kerbside containers. It should also be complemented by norm-activating information [75]. Such information could strengthen the effect since the information will underline the economic incentive. A trust in the environmental effectiveness of the system is an important determinant for the attitudes towards recycling schemes [76].

\subsection{Developed Recycling Systems}

\subsubsection{Description and Assumptions}

Source separation can be negatively affected by practical aspects as well as uncertainty among people [43]. The collection system can be improved to make things easier for the households, for example through kerbside collection (reduced transport distance for the household) or by a collection system based on material streams (e.g., plastics) instead of product groups (e.g., packaging). The policy instrument evaluated in this study represented a combination of these, property-close or kerbside collection of material streams [20].

\subsubsection{Results of the Evaluation}

Hage et al. [69] provide an econometric analysis of the collection of plastic packaging waste across almost all Swedish municipalities, and show that the presence of kerbside recycling and the number of drop-off stations per square kilometer, respectively, have significant impacts on the reported collection rates. Also Söderholm [75] emphasize the relation between increased availability of recycling opportunities for the households and increased collected amounts of recyclables. This indicates an overall important potential to increase collection by improving the collection infrastructure.

Kerbside collection increases the costs of collection and transportation for the waste management company, and this can be relatively high in sparsely populated regions (e.g., Kinnaman [77]). On the other hand, the transport needs for the households decreases. Previous studies indicate that the frequency of travels for the sole purpose of dropping off waste is often relatively high [75]. If households in general do not combine travels for drop off of packaging waste with other travels, overall transportation costs could actually be reduced through the introduction of kerbside collection. 
This is because the introduction of kerbside collection means that the uncoordinated trips of households to the recycling stations are displaced by centralized transport pick services.

Another way of developing the collection system is to collect waste in material streams instead of the current Swedish system where only packaging materials and paper are collected. A pilot test where plastic and metals from households were collected was organized by the Swedish EPA [78]. The results indicate that the system would be easier for households to understand and that their motivation would increase and therefore also the collection of recyclable materials. This would have environmental benefits. In order to ensure that the collected materials would be recyclable, further measures may, however, be necessary [78].

Andersson et al. [44] draw the overall conclusion that developed collection systems (including property-close collection and/or collection in material streams) can be an effective way of increasing the collection from households. This, however, requires that systems are adapted to the needs of the households, the knowledge and motivation among households are increased, and the number of fractions that are sorted at home should preferably not increase.

Based on the evaluations made, developed collection systems would likely contribute to increase recycling and positive environmental effects but the magnitudes of these effects are uncertain. The advantages are that the customer may see it as a higher level of service and that the facilitated collection may increase the amount of waste collected [44]. However there are also some drawbacks like increased needs for heavy transport (on the other hand the household's transports of waste will decrease).

\subsection{Tax on Virgin Raw Materials}

\subsubsection{Description and Assumptions}

In order to reach an efficient use of raw materials, taxes should be introduced if there are significant external costs associated with raw materials extraction or use. Since there are environmental impacts associated with extraction of raw materials that are not internalized, a raw material tax can increase the economic efficiency and reduce environmental impacts. Moreover, if the market actors are using a higher discount rate (rate-of-return requirement) than what is socially optimal, too much material could be extracted. In order to change this, a raw material tax can increase the efficiency. Raw material taxes can also be used as a second best option to reduce environmental impacts further down in the product chain [50].

Taxes on raw materials can be designed in a number of different ways [50]. They can be broad taxes covering a large number of materials or more specific taxes for selected materials. Sweden already has a tax on natural gravel and an energy tax on fossil fuels. In this program we have evaluated two broad raw materials tax proposals, both described by Bisaillon et al. [20]:

- A $10 \mathrm{SEK} /$ ton tax on non-renewable materials (excluding fossil raw materials and plastics) extracted or imported and then used in Sweden.

- A tax on all fossil raw materials similar to the one currently applied on household heating oil $\left(3804 \mathrm{SEK} / \mathrm{m}^{3}\right)$ and an associated $5000 \mathrm{SEK} /$ ton tax on imported plastics. 
Forsfält [27] analyzed the impacts of each of the two taxes separately using the EMEC model. The assessment of the first tax was limited to a test on how a tax on the mining of metals in Sweden affects the economy and waste generation. Adjustments were made so that exports were not taxed while imports should be taxed similarly to domestic production. No attempts were made to analyze how the economy is affected by a tax on raw materials in refined products. The analysis with EMEC was complemented by more conceptual analyses [48] as well as a synthesis of the empirical experiences of aggregates taxes in Europe [50].

\subsubsection{Results of the Evaluation}

The EMEC results on the $10 \mathrm{SEK} /$ ton tax on metals and mining waste indicate that the impact on the total amount of waste is relatively small: the demand for products from the mining industry decreases somewhat [27]. Sectors "downstream" are affected since the relative price of ore increases; how much depends on companies' ability to substitute between different inputs. For the iron and steel industry and other metal industries, the possibilities for substitution are assumed to be limited and therefore the value added falls in these sectors. Production levels in other sectors of the economy are almost unaffected, as is the total GDP and household income. The total quantity of non-hazardous wastes in the EMEC model for the year 2030 is reduced by 30-40 ktonnes (depending on scenario). The quantity of hazardous waste is reduced by $4-6$ ktonnes.

When interpreting the results it should be noted that only some of the possible impacts are included in the model. The possibilities for switching between metals and other materials are possible, but the change from virgin metal products to recycled metal products is not modeled in EMEC. Since this is a change that can be expected, and a change that could also alter the waste amounts, the possible reduction in waste amounts in Sweden may be underestimated. In addition, only impacts in Sweden are included in the model.

The results of the model experiments concerning the second raw-materials tax, 5,000 SEK/ton plastics were different in structure, this since all production sectors in the economy are affected [27]. However, the model results suggest that the net effect on waste generation is still small. The tax actually increases the quantity of non-hazardous waste in the scenario "Global markets". In other scenarios, the quantity is reduced by $7-13$ ktonnes. The quantity of hazardous waste is reduced by 4-6 ktonnes in the model, again depending on the scenario.

The small effects on the waste flows means there are almost no changes in terms of environmental impacts: each of the two taxes results in less than $1 \%$ of improvement in each impact category according to the results from the LCA model SWEA [30].

These results are consistent with empirical experiences of virgin materials taxes in Europe [50], which suggest that they may have little effect on the use of recycled materials unless they are complemented by measures to promote waste sorting activities.

In the long term, Forsfält [27] argues, a combination of taxes on specific raw materials and broad taxes are probably most effective. Söderholm [50] in turn argues, in line with Walls and Palmer [74], that the policy instrument can preferably be combined with policy measures that promote increased waste sorting (e.g., at construction and demolition sites). Walls and Palmer [74] find that no single tax can generate the optimum level of both downstream and upstream waste disposals and that multiple 
policy instruments are necessary to fully internalize the externalities. These results are also empirically illustrated in Palmer et al. [79]. The material tax in itself can be expected to have moderate effect because own-price elasticity of demand is often low for materials. The effect on recycling is likely to be even lower, because the supply of recyclable material is also not very sensitive to changes in price. The effects will however depend also on the level of the taxes.

The development of raw material taxes requires some additional work before they can be implemented. Especially issues related to imports and exports may be problematic and need some further considerations. According to Ekvall et al. [48] the effect on the competitiveness of the Swedish industry will be much smaller if the tax is not calculated based on the quantity of materials extracted or imported to Sweden, but on the estimated quantity of non-renewable raw materials that are extracted to produce products that are used in Sweden. This might allow for introducing raw materials taxes that are much higher than the $10 \mathrm{SEK} /$ ton investigated here. Such a tax could have a much greater impact on the material efficiency of the economy and, hence on the waste quantities.

It should be noted that a high tax on virgin raw materials is ineffective if it mainly means that products based on virgin raw materials are used in other countries, while Swedish citizens use products based on recycled materials. In this situation, the tax affects the transportation patterns of materials and products, but it does not significantly affect the material efficiency or the global recycling rate. This ineffectiveness is comparable to the lack of effects of a national system of tradable recycling certificates for materials with a well-established, international recycling market (see Section 3.4).

\subsection{Advertisements on Request Only}

\subsubsection{Description and Assumptions}

This policy instrument prevents companies from direct advertising to mailboxes without a posted sign saying yes to advertising (the opposite from the present situation when household have to say no to such commercial advertising) [20].

\subsubsection{Results of the Evaluation}

"Advertisements on request only" have the potential to reduce the annual wastepaper quantity by up to $12 \mathrm{~kg} /$ person and year with current levels of paper consumption [20]. For Sweden this corresponds to 0.11 Mtonne/year (ibid.). This amounts to about a $20 \%$ reduction in the waste intensity coefficients for paper waste from households [42]. The reduction in paper waste is expected to result in a corresponding reduction in environmental impacts from the production of the paper leading to overall reduced environmental impacts [80]. However, part of the effect may be offset by more paper being used for other purposes and/or in other countries and that it can increase the production of other types of advertisements [42].

From a psychological and ethnological perspective, Andersson et al. [44] assess this policy instrument to be both effective and legitimate. It makes the environmentally friendly alternative the default alternative, thus contributing to an overall alignment of values and policies. A disadvantage may be that for some groups it could potentially be more difficult to get access to some local and commercial information. 


\subsection{Differentiated VAT}

\subsubsection{Description and Assumptions}

A differentiated value added tax (VAT) could aim at shifting households' consumption from goods to services and to eco-labeled goods [20]. This could make the consumption more environmentally friendly and less material-intensive.

Using the EMEC model, Forsfält [27] studied the effects of such a differentiated VAT on the Swedish economy and on future waste quantities. The proposal evaluated by Forsfält [27] is that the VAT on all households' consumption of services except transportation should be equal to the currently lowest VAT rate, which implies a reduction from the present 25 (or 12 ) $\%$ to $6 \%$.

\subsubsection{Results of the Evaluation}

The EMEC results depend on the way the tax cut is financed. If it is financed by a decrease in government transfers to households, the consumption of services in the year 2030 increases by $3.6 \%$ and households' waste generation falls by about 1 percent, compared to a scenario without this policy instrument [27]. The consumption of goods falls but total consumption expenditures are almost unchanged. Investments fall marginally as do imports and exports. The GDP decreases by $0.1 \%$. Production increases in the service sectors at the expense of commodity producers, but the relative increase in the service sector's value added $(0.3 \%)$ is less than the increase in service consumption (note that the service industries production is considerably larger than households' consumption of services).

If the tax cut is instead financed by increasing the VAT on goods, then the change in the consumer price of services relative to that of goods is greater, something which in turn causes waste generation to fall by about $1.5 \%$ [27]. Also in this case, GDP decreases by about $0.1 \%$.

The results thus show that the waste is reduced more than GDP due to the VAT change. It is the redistribution of consumption that provides the reduced amount of waste. Forsfält [27] concludes that differentiated VAT provides a change in a more sustainable direction although the model results indicate that the resulting waste reduction is modest.

The environmental impact assessment was performed on the case where tax cut is financed by a decrease in government transfers to households, resulting in a waste reduction by $125 \mathrm{ktons}$. The results indicate environmental gains mainly through avoided production of food, textiles, and steel, according to results from the SWEA model. The expected improvement varies across the impact categories, in the range of $1-7 \%$. For climate change the environmental gain in SWEA is $5 \%$ [30]. It is interesting to note that the reduction of environmental impacts is larger than the reduction in waste volume. This is an indication of the importance of waste prevention. Households' real incomes are not affected significantly by the investigated change in VAT, which means that households' total consumption capacity only decreases marginally [27].

In conclusion, the introduction of a differentiated VAT seems rather unproblematic according to these assessments and gives a change in a more sustainable direction. The indicated waste reduction is small but a combination with other instruments, such as information, could improve efficiency. 


\subsection{Environmentally Differentiated Waste Fees}

\subsubsection{Description and Assumptions}

An environmentally differentiated waste fee would provide lower fees for households and companies that sort out more fractions. The idea behind environmentally differentiated waste fees is to achieve a stronger link between household waste fees and the environmental impact of the waste treatment [20]. This type of policy measure is already in use in some Swedish municipalities, e.g., when households separate food waste for biological treatment and then get a lower waste fee (ibid).

In our evaluation, it is assumed that the introduction of the policy measure would give incentives for $20 \%$ of the households and firms to sort in three fractions (food waste, packaging and combustible) and that these actors sort out $60 \%$ of their food waste and $50 \%$ of the packaging materials.

\subsubsection{Results of the Evaluation}

One benefit of this policy instrument is that it provides a clearer connection between the fees and the environmental impacts of waste treatment [44]. It will contribute to an alignment of environmental impacts, policy and norms. However, there may be a risk for fraud and dumping in order to get lower fees in the same way as for weight-based waste fees. This instrument should thus be complemented with norm-activating information. Andersson et al. [44] suggest that environmentally differentiated waste fees should also be combined with improved collection systems. Then the households would face less barriers as well as stronger incentives to sort more efficiently and the fractions could be cleaner. The environmental benefits of this policy instrument can be assumed to be similar to a weightbased waste-collection fee that results in increased source separation and recycling (see Section 3.6).

\subsection{Improved Information}

\subsubsection{Description and Assumptions}

The evaluation includes both information to households and information to companies and organizations. Bisaillon et al. [20] mention two principal information categories:

- Procedural information, telling for example how, where, and when people should hand over source separated or non-separated waste.

- Declarative or norm-activating information, aiming at giving people motivation why they should source separate and the effects of source separation.

In the analysis, it has been assumed that information is combined with other policy instruments when they are implemented.

\subsubsection{Results of the Evaluation}

The effects of information on waste flows and waste treatment are difficult to quantify. Ekvall et al. [42] suggest that an effective and persistent information campaign could reduce the waste quantity from households in the year 2030 by $10 \%$. They argue that the effect on waste from companies is likely to be smaller. However, these effects will depend very much on the details and context of the information. 
Andersson et al. [44] assess the acceptance of information as a policy instrument. This assessment covers both information to households and information to companies, and includes a discussion of how the information should be designed to provide the desired effects. For example:

- Information should be combined with other instruments, for example to make way for other policy instruments.

- Information should be adjusted for each recipient group.

- Information can be given in the form of feedback.

- Information should be conveyed by a credible source.

- Information should rely on ethical norms of what people should do.

- In Sweden, the environmental awareness is generally high. Declarative information is then less important, but it is necessary for groups with low environmental awareness.

One difficulty with information is to reach the recipients, because of the high total information pressure on people. The message is often not noticed if it is not relevant for the recipient at the moment it is received. Another difficulty is that paying attention to the information is voluntary. People who are not interested in waste can simply neglect any information provided.

Andersson et al. [44] still conclude that information is important for the future waste-management, especially in scenarios with a high degree of environmental awareness. Information can be an effective policy instrument in several ways. As a separate instrument it can be used for both affecting the behavior and giving procedural information. It is a necessity when implementing other policy instruments, for example when paving the way for the instruments. The effect of information can also be catalyzed in combination with other instruments. This is also in line with the results of Brekke et al [81] indicating that perceived responsibility is a determinant for reported recycling behavior, but also that uncertainty in the information for example about other people's behavior could cause reluctance to accept responsibility. Also Bruvoll and Nyborg [82] conclude that people are willing to conform to social norms, even if it comes with perceived costs in terms of time or work.

\subsection{Mandatory Labeling of Goods Containing Hazardous Substances}

\subsubsection{Description and Assumptions}

Bisaillon et al. [20] describe this policy instrument as a requirement to label all goods containing at least $0.1 \%$ substances with very high acute toxicity, allergenic, high chronic toxicity, mutagenicity, or other hazardous properties. Examples of goods that could be labeled are, for example, furniture, shoes, clothes, toys, electronic devices and other goods that people usually do not associate with hazardous content. Chemicals, pesticides, solvents and similar are not concerned since they already are included in other labeling rules and regulations.

\subsubsection{Results of the Evaluation}

Ekvall et al. [42] suggest that mandatory labeling can affect consumer choices and reduce the use of such products. It would thus contribute to waste prevention by minimizing the hazardousness of waste. Andersson et al. [44] mention several advantages with this policy instruments: 
- The consumers themselves decide if they want to contribute to a better environment when shopping.

- If there are alternatives, the consumers will have the possibility to avoid products containing hazardous substances.

- Consumers without an active interest in environmental issues can still be prone to avoid exposing themselves and their family to hazardous substances. This is likely to make negative environmental labeling (of hazardous substances) more effective than positive environmental labeling (eco-labeling).

Among the drawbacks the following can be noted [44]:

- The system must be mandatory. A voluntary system can lead to confusion if a lot of products and trademarks are not included.

- It is easier for a manufacturer to accept an eco-labeling system.

- There are examples when the labeling can lead to confusion, e.g., if a product has both positive and negative environmental properties.

All together Andersson et al. [44] conclude that labeling of environmental hazardous substances is likely to be an effective policy instrument to decrease the content of hazardous substances in the waste.

\section{Discussion}

The present study is fairly unique in its scope. Many of the existing policy instruments and also much of the scientific literature tend to focus on specific waste types such as packaging $[83,84]$ or WEEE [85-87], or on municipal waste. This study instead takes on a broader perspective and has addressed the whole national waste management system and its stakeholders. Therefore it deals with many different policy instruments, which are evaluated from several perspectives, and that in turn can be implemented at various parts of the system and for many types of waste. This makes it possible to identify policy combinations and compare different instruments and policy mixes, both existing and not yet implemented ones. Based on the learnings from our and other assessments some conclusions can be drawn on the implications for Swedish waste management policy, which policy instruments that have potential, what needs to be developed further, and parts of the system where more and innovative policy instruments are needed.

\subsection{Development of Policy Instruments towards Implementation}

The evaluations summarized above show that some policy instruments have the potential to contribute to more sustainable waste management, whereas other show a low potential or need for redesign. This section includes brief discussions on the instruments that showed potential in the evaluations and with suggestions for adjustments and redesign.

\subsubsection{Compulsory Recycling of Recyclable Materials}

Compulsory recycling of recyclable material can lead to a high environmental gain compared to the potential environmental impacts of the business as usual scenario (c.f. Ambell et al. [4]). This is 
therefore a policy instrument that should be further investigated. There are financial costs for increasing material recycling, but there are significant environmental gains to be made. A number of aspects need to be further studied. Which materials or products should be included and to what extent? Should there be an existing market for the recycled material or is it enough if it can be expected to develop? What are the costs for recycling of individual materials and what are the environmental benefits? What are the implications if international waste trade is considered as well?

\subsubsection{Weight-Based Waste Fee in Combination with Information and Developed Collection Systems}

A weight-based fee is already used in several Swedish municipalities and would be relatively easy to introduce in others. Although experience indicates reduced collection of waste, the reasons for the reduced waste and thus the potential environmental impacts are uncertain. However, in combination with other policy measures it might have a larger effect and Schmidt et al. [71] found that it seems to function more as an information instrument than as a financial incentive as it gives positive feedback on the right waste handling practice. Since there might be a risk of illegal waste treatment involved, it could be a good strategy to combine this policy instrument with an improved recycling system and increased information on the negative consequences of, for example, uncontrolled burning.

\subsubsection{Mandatory Labeling of Products Containing Hazardous Chemicals}

An important part of waste prevention is to minimize the content of hazardous substances in the waste. Waste policy is therefore linked to chemicals policy. Labeling of products containing hazardous chemicals can be a useful instrument. However, it probably needs to be implemented at the international level for example within the European Union. Sweden can take a role in developing such an initiative.

\subsubsection{Advertisements on Request only and Other Waste Minimization Measures}

Advertisements on request only can be efficient as a policy instrument since it is expected to have an impact on the reduction of paper waste, and most people are expected to accept. This is an example of a waste minimization policy measure. There are others, for example supporting re-use of products by making it easier for people and organizations to sell or give products to charity before they become waste, to reduce food waste, and to reduce beverage packaging [88-91]. Each one of these waste minimization policy measure tends to have a rather limited impact in terms of reduced waste amounts. However, if waste minimization also leads to reduced production, the environmental gains can be larger than the reduced waste amounts indicate. Several measures together can therefore make significant contributions.

\subsubsection{Differentiated VAT and Subsidies for Some Services}

According to our assessments, a differentiated VAT where the tax is reduced for services is expected to be beneficial in terms of environmental impact due to a redistribution of consumption. The households' real incomes are not affected significantly. The indicated waste reduction is small but a combination with other instruments, such as information, could improve efficiency. 
In order to achieve more significant impacts it would be interesting to test a more extended VAT differentiation. In Sweden the standard rate today is $25 \%$, but this could possibly be increased while VAT on households' consumption of services could be decreased even more compared to the tax changes that have been evaluated. Changes in VAT would have other macroeconomic effects, such as impacts on employment. A differentiated VAT could thus be of interest in a broader tax reform.

This policy instrument could also be made even sharper by not only reducing VAT but also introducing subsidies to certain services such as leasing, repairing, renovation and second hand in parallel to current subsidies on domestic services.

\subsubsection{Information}

Information is a necessary policy instrument in order to successfully implement most other policy instruments. It is necessary but not sufficient in itself. In order to be efficient, information should be combined with other tools and designed in relation to the specific situation

\subsection{New Ideas for Policy Instruments}

Besides the policy instruments evaluated and discussed above, there are several other instruments that are of interest for further development. Some of these are discussed below as well as some instruments that were evaluated but need modifications.

\subsubsection{A General (Raw) Materials Tax}

Taxes on the use of raw materials are likely to be necessary in a more sustainable society. They can be designed in a number of different ways and further work in this area is needed. A possible development of the tax on non-renewable raw materials discussed above is a materials tax where the tax is the same for virgin and for recycled material. This policy instrument could serve to increase material efficiency all through the life cycle since materials will become more expensive. If a high materials tax is introduced in Sweden, however, measures must be taken not to hamper the competitiveness of the Swedish industry. Such a measure could be to extract the tax on materials and products used in Sweden only, and on imported products as well as on domestically produced products.

\subsubsection{Re-Use Certificates}

As a further development of recycling certificates, it is possible to conceive a system of reuse certificates. This would stipulate that a specific share of a specific type of products or components, for example bricks or roof tiles in new buildings, should be reused. Certificates would be awarded to construction companies that, to continue the example, reuse bricks or roof tiles. If a construction company has a lower share of reused bricks than stipulated by the policy instrument, they would need to buy certificates from companies that reuse more than they need. This policy instrument could serve to create markets for reused components and products. 


\subsubsection{Bringing down Transaction Costs}

There may be high search and transaction costs associated with recyclable materials related to incomplete information [92]. Users and suppliers of recycled materials can have problems finding each other. There can be a lack of information about the quality and properties of potentially recyclable or reusable materials and products. In addition, the information may be asymmetric so that the supplier knows more about the material or product than the potential buyer. A broad range of policy instruments can be used to support the markets in these situations. Examples include support for establishing market places, information hubs or hiring waste brokers. It can also be useful to support the establishment of different certification schemes and quality standards. Also requirements to provide information on the content of different materials, e.g. in products or building materials, may be useful. Users may lack knowledge about how to use recycled materials, for example in the production of new products. In such situations, information and education of users, e.g. product designers, could be useful. Other examples include supporting industrial symbiosis by removing institutional barriers for increased recycling of industrial by-products and wastes (e.g., Watkins et al. [93]). Many of these initiatives exist already today, but there is a need to investigate and develop these instruments further. Many waste management policy studies in the environmental economics literature (e.g., [73,74]) assume implicitly the presence of efficient private markets for recycled materials. Only a few analyzes the case of second-best optimums assuming that recycling markets are not operating (e.g., [94]), while Calcott and Walls [95] represent one of few studies addressing the presence of existing — but imperfect -recycling markets.

\subsubsection{Requirement of Design for Recycling}

Another type of barrier may be the existence of technological externalities [92]. An example of such an externality is if the production of a product is made in such a way that the cost of recycling is increased, but neither the producer nor the buyer of the product has to pay for this extra cost. A concrete example may be the current design of dishwashers which often makes it difficult and costly to dismantle it in a way that the copper can be separated from the steel, making the recycling of both the copper and the steel less effective [96]. If this extra cost for dismantling is not covered by the buyer or seller of the dishwasher, an external cost is passed on.

Calcott and Walls [95] note that in practice it is difficult for policy-makers to attain a first-best outcome in the case of these design issues, primarily since product-specific taxes that vary with the degree of recyclability are difficult (and costly) to implement. Strong incentives for recycling design require, though, that recyclers keep track of exactly which firms' products they are recycling. Extended producer responsibility, if the responsibility is individual for the producing companies, may be a way of moving the extra costs of recycling to the producer and thus providing an incentive for a better design. If the extended producer responsibility is collective, this incentive will however not exit, and the technological externality will still be there. A requirement for design for recycling may in this case be more effective. This could possibly be introduced in the Ecodesign directive [20]. 


\subsubsection{Tax on Hazardous Substances}

Very hazardous substances should be banned from use. There will however always be substances that society cannot or does not want to ban completely, but still want to minimize the use of. Taxation on the use of hazardous substances can be made in different ways [97]. Taxes can, for example, be put on specific substances. The idea is that the use of these substances will decrease and, eventually the waste may contain less of the hazardous substance and become less hazardous. Taxes can also be placed on all substances fulfilling certain criteria. Different options for the taxation of hazardous substances should be further developed and evaluated.

\subsubsection{Deposit and Refund Systems}

Deposit and refund systems where the buyer of a product pays a deposit which is paid back when the product is left for waste treatment can be an effective instrument for making sure that products are collected in a proper way. This is a type of instrument to be used for product groups of special importance. In some cases, a refund, or a bonus, could be paid without actually having collected a deposit, to make sure that products are collected. This could be relevant for products for which the environmental impacts would be especially worrisome if the waste products are not properly handled.

\subsubsection{A broader Landfill Tax}

Many waste materials are currently exempt from the landfill tax in Sweden. This is the case for waste fractions where there are no alternative treatments. With such exempts there are, however, little incentives for developing new waste treatment methods or for waste minimization. It could therefore be useful to introduce a lower landfill tax also for these waste materials. This tax should preferably correspond to the environmental costs of the landfilled waste, and is endorsed in previous studies. For instance, Kinnaman [77] argues that landfill taxes are typically inexpensive to administer and unlikely to cause illegal dumping. In many ways it may reduce the need for other initiatives, such as weight-based fees and kerbside collection

\subsubsection{Required Storing of Plastics that Cannot be Recycled}

In most cases, recycling of plastics is the most environmentally friendly option (e.g., [98-100]). However, if recycling is not possible, storing or landfilling of plastics can produce less emissions of gases contributing to climate change compared to incineration, at least in the time perspective of a century or shorter, even if the heat and electricity production from the incineration is credited by assuming that it replaces energy sources typically used in Swedish and European conditions [101]). Storing of plastics is however currently not allowed because of the landfill ban on organic and combustible materials. A change in this policy could be one of the most effective ways of reducing the emissions of greenhouse gases from the waste sector. 


\subsubsection{Increased Control and Monitoring by Authorities}

This policy instrument means that more resources are allocated to monitoring and control of industry and other commercial activities, particularly regarding the waste management [20]. The control can be both within the existing areas of control or more specific on for example waste prevention. The idea is that increased control by the authorities would lead to an increased awareness regarding wastes which would lead to a decrease of hazardous waste in mixed waste and increased sorting in general. This might in turn lead to, for example, more waste being recycled and decreased amounts of hazardous waste.

\subsubsection{Waste Minimization in Enterprises (Industrial Waste-plan Requirements)}

Bisaillon et al. [20] describe several alternative policy instruments for waste minimization in enterprises. One is to require a waste plan, including plans for waste minimization, from companies generating more than 2000 tons/year non-hazardous waste or more than 2 tons/year hazardous waste. These figures are in accordance with the requirements in the Environmental Code to submit an annual environmental report. Another alternative is to require detailed descriptions of activities to minimize waste when applying for environmental permits and in the annual environmental reports require a follow-up of these actions and continuous up-dating of the minimization plan. For all of these alternatives the policy instrument aims at creating conscious and permanent deliberations on waste prevention and recycling in the companies.

\subsection{Choosing and Combining Policy Instruments}

One important conclusion from the assessment is that many different policy instruments can be used to further develop the waste management system in a more sustainable direction. In this section we discuss the scope for considering different types of policy combinations. The rationales for relying on policy mixes rather than isolated policy instruments are several. One argument, typically highlighted in environmental economics literature, is the difficulty in monitoring individual recycling behavior and thus the presence of illegal dumping. This calls, as argued above, for a combined output tax and recycling subsidy (equivalent to a deposit-refund system) [73]. Moreover, several policy instruments affect different parts of the waste management system and may address different types of market failures. Apart from environmental effects, policies are needed to address information problems, recycling design incentives etc. (e.g., [92]). Waste management policies must also take into account different political constraints and issues of public acceptance (apart from economic efficiency concerns and environmental effectiveness) (e.g., [102]).

Among the studied policy instruments, one in particular has the potential to significantly reduce the environmental impacts: "Required recycling of recyclable materials", provided that the recycled material can replace virgin material. In Sweden the bans of landfill disposal of organic and combustible materials has moved a lot of waste one step up in the waste hierarchy, from landfill to incineration with energy recovery. A requirement to recycle materials that can be recycled would move waste an additional step up in the hierarchy. This suggestion is also in line with the European Commission road map for a resource efficient Europe. The assessment presented here indicates that the 
costs are not prohibitory high compared to the environmental benefits. Before being implemented it will, however, need more assessments looking into costs and markets of recycled materials.

Moreover, many of the discussed policy instruments steer in a more sustainable direction although the impacts of several of these are rather limited. This suggests that many instruments need to be used in combination. It also suggests that they should be adjusted and some of them need to be further developed.

An effective strategy for decreasing the environmental impacts of waste management is in most cases to increase recycling. What policy instruments contribute most to an increase in the global recycling rates depends on whether or not there is a well-established, international recycling market. For materials where such a market exists, Swedish policy instrument should primarily focus on increasing the collection for recycling. The collected recyclables can be assumed to displace virgin materials in the international market where the two compete. This is because the marginal production of the material is likely to be based on virgin materials.

A policy instrument that focuses on increasing the use of recycled materials only in Sweden may be relatively ineffective in a situation where the established recycling markets are international. In such situations, an isolated support to the use of recycled materials in Sweden, may result in a lower recycling in other countries, and therefore not a globally increased recycling. It should therefore preferably be combined with policy instruments supporting the supply of recyclable materials, in order to increase global recycling [50].

A broad range of policy instruments are available to increase collection for recycling and thus the supply of recyclable materials. These include, for example, requirements to recycle recyclable materials, weight-based waste-collection fees, broader and tighter extended producer responsibility, requirements on curbside collection, deposit-refund systems, requirements on design for recycling, etc.

For materials where a recycling market does not exist, or when it is not well established, the reason is often a low demand for the recycled material. In such cases, the policy instrument could focus also on stimulating the demand for the recycled material, thus helping to establish the market. Examples of initiatives and policies that can be used to help establishing recycling markets include support for developing new recycling technologies (e.g., pilot and demonstration plants) and initiatives to decrease transaction costs. Green public procurement requirements can be used to demand a certain amount of recycled material in products and materials, which may be instrumental in developing a market.

A tax on virgin raw materials is another possible policy instrument that could support the establishment of recycling markets. It will not force recycling into existence, but it might stimulate technology and systems that make recycling feasible. Also in this case, supply-oriented policies would be a useful complement.

Reducing the amount of waste is top priority in waste policies and it can be done in several different ways. One may be to reduce the production volume and thus the waste from the production and after consumption. Another may be to change the production from more waste intensive products and services to less. A third is to change the production process to become less waste intensive. A fourth may be to make sure that products and materials are re-used or recycled before they become waste.

Increasing the costs of waste disposal could, in theory, reduce the amount of waste by all the mechanisms described above. Our general equilibrium model results indicate, however, very little to no changes in waste volumes resulting from changes in the marginal costs of waste disposal [24]. 
These results indicate that changes in the waste-management system may have little effect on the production, unless costs are raised to a much higher level than today. This outcome is reasonable, because even an increased cost of waste management constitutes just a small share of the overall cost of most businesses. Increased waste disposal costs could, however, still influence the waste treatment, for example by making recycling more economically attractive.

Another strategy to reduce the generated waste amounts may be to stimulate material efficiency by increasing the purchase cost of materials. This could be done by introducing raw material taxes which would make virgin raw material more expensive and/or by material taxes that hits both virgin and recycled materials. Another way of making materials more expensive is to tax environmental externalities from raw material production. For example, industrial wastes, including mining wastes, are largely exempt from the landfill tax in Sweden. If landfilled mining wastes would be taxed, this would increase the raw material costs in a similar way to the raw material tax analyzed here. The advantages and disadvantages would therefore be similar to those discussed above in relation to raw material tax.

As indicated by the discussion, a number of policy instruments can be used to support an increased recycling and decreased waste generation. The appropriate mix may depend on whether there are established recycling markets or not and, if not, what are the barriers for establishing such markets. If a recycling market does not exist today for a specific material, it might still be established in the future. In fact, one of the aims of some of the policy instruments could be to stimulate the establishment of such markets. A dynamic set of policy instruments could be designed as follows:

1. The material in question cannot be recycled. Technological development is supported to find recycling possibilities with environmental improvements. A tax on virgin raw materials is introduced to stimulate the development of technology and market for recycling.

2. Recycling of the material is possible but markets are not established. Further technological development is supported as well as tools to establish markets: for example, information systems, certifications, procurement requirements, waste brokers, and requirements for design for recycling.

3. A market has been established. A requirement to recycle is introduced together with other policy tools that support the supply of recyclable materials.

The policies evaluated above that focus on reducing waste amounts, have in general rather limited impacts. In order to radically decrease the production of waste, and transform norms and habits, more transforming policy instruments may therefore be needed, i.e., instruments that can cause social and cultural change and break current trends. Policy instrument that could start or enhance such change need to be perceived and experienced as meaningful for the recipients. This means that the instruments must be grounded in everyday life and 'mind'. They must correspond to something that, however costly, is fairly straightforward to do and understand, and it must give a real or abstract gain. If these criteria are met it means that the instruments should be intelligible, comprehensible and perceived as legitimate [103]. Even if an instrument is perceived radical, and therefore meets resistance, it does not mean that it is wrong to introduce it to begin with. In this case, the policy instrument could function as a 'stage for reflection' [104]. 
When introducing a radical measure, significant social consequences could in many cases be expected. There is always a risk for a backlash, with people finding ways not to co-operate or comply with the measures. But in addition to protest the affected public is also likely to be stimulated to come up with ideas and demand improved or new options for patterns of actions in everyday life. This means that parallel introduction of supplementary measures could seem reasonable in the public view. Such measures could also be used to adjust for perceived unfair distribution effects (of costs and inconveniences). However, somewhat paradoxically, negative publicity from features such as dramatic political processes or conflicting interests can lead to debate and media coverage that enhance public knowledge concerning how the instrument works. Such knowledge could actually pave the way for the understanding of a policy instrument and its implementation [105].

Today's well working, and publicly accepted, policy instruments seem to be grounded in a certain kind of reciprocity, 'the authorities arrange environmentally sound recovery so I pull my weight' [103], or more generally, people perceive they give something (i.e., pay) to receive something else [106]. From the ethnological point of view, policy instruments could be seen as a way of negotiating environmental problems or conflicts [107]. Policy instruments could actually be a rather good way to create large-scale cooperation. If we are to see policy instruments as a way of negotiating, then the negotiating parties are industry, authorities and people, with the internal conflict between the roles of the citizen and the more self-interested consumer or producer/employee [103]. The very notion of the environmental protection also plays a role (c.f. [47]).

When looking at current waste handling we find that sorting packaging to some extent is no longer being negotiated and therefore can be said to be agreed upon [43]. This indicates that authorities who introduce and maintain policy instruments have successfully mediated between citizen interest and consumer interest. Both the citizen and the consumer seem to benefit.

Correspondingly the conditions for waste minimization are still not agreed upon and must be settled in future negotiations. If we view a policy instrument as a mediator in a negotiation between different parts in a conflict, it is important that the mediator does not lose its status/power.

When we studied implementation of policy instruments such as recycling of packaging, we came to the conclusion that policy instruments and their contexts will always be in a state of flux. This means that they need to be maintained, adjusted and complemented at intervals. Governance of an environmental policy instrument must be active [103]. Solutions should to our minds be seen as associated with the negotiation of rules, restrictions and sanctions for the protection and management of natural resources $[108,109]$. We have found it important to start to qualitatively assess how the regulations function for people's (culture-characterized) ways of thinking and acting. The concept negotiation provides a perspective on the relationship between actors with the power to introduce regulations and the groups whose everyday lives are affected.

In the long term, it will not be possible to 'entice' people to conform to the regulations and the system if these do not produce the promised or expected outcome. Therefore we need to regularly determine whether people perceive that the regulations and systems fulfill their function [103]. This should be assessed both on the societal level and in nature. From a scientific point of view, improved theoretical frameworks, methods and interdisciplinary syntheses are needed to make better such assessments. From a societal point of view co-evolution of policies, technology and socio-cultural practices are needed to achieve waste minimization and sustainable waste management. 
Many of the policy tools discussed above show interesting results in the evaluations. Some focus on preventing waste to arise in the first place, while others focus mainly on managing waste that has arisen. In order to significantly reduce waste amounts, more radical changes may be needed. That is why we have also discussed aspects of transforming policy instruments that break current trends. But more work is also needed before a detailed design of such tools can be suggested.

\section{Conclusions}

Through the assessments and lessons learned in the research program TOSUWAMA, we can establish that several policy instruments can be effective and lead towards a more sustainable waste management system. They also seem possible to implement. Particularly, we put forward the policy instruments "Information"; "Compulsory recycling of recyclable materials"; "Weight based waste fee in combination with information and developed recycling systems"; "Mandatory labeling of products containing hazardous chemicals", "Advertisements on request only and other waste minimization measures"; "Differentiated VAT and subsidies for some services". Compulsory recycling of recyclable materials is the policy instrument that has the largest potential of decreasing the environmental impacts. The effect of the other policy instrument as evaluated here could be limited and they need to be redesigned or used in combination in order to reduce environmental impacts more significantly. Furthermore, efforts are needed to take into account market and international aspects. In the more long term perspective, this set of policy instruments may need to be complemented with more transformational policy instruments that can significantly decrease the generation of waste.

\section{Acknowledgments}

This paper summarizes some of the results from the six-year research program "Towards sustainable waste management" [19]. Besides the authors a large number of people have contributed, including researchers, members of reference groups and participants in workshops and conferences. We are grateful to all these as well as to the Swedish Environmental Protection Agency for funding this research. Also comments from anonymous reviewers are appreciated.

\section{Conflict of Interest}

The authors declare no conflict of interest.

\section{References and Notes}

1. European Commission. Roadmap to a Resource Efficient Europe; COM (2011) 571 Final; European Commission: Brussels, Belgium, 2011.

2. Rockström, J.; Steffen, W.; Noone, K.; Persson, Å.; Chapin, III, F.S.; Lambin, E.F.; Lenton, T.M.; Scheffer, M.; Folke, C.; Schellnhuber, H.J.; et al. A safe operating space for humanity. Nature 2009, 461, 472-475.

3. Swedish EPA. Steg på vägen. Fördjupad utvärdering av miljömålen 2012 (Step by Step. In Depth Evaluation of Environmental Objectives 2012); Report 6500; Swedish EPA: Stockholm, Sweden, 2012. 
4. Ambell, C.; Björklund, A.; Ljunggren Söderman, M. Potential för ökad materialåtervinning av hushållsavfall och industriavfall (Potential for Increased Material Recycling of Household Waste and Industrial Waste); TRITA-INFRA-FMS 2010:4; KTH Samhällsplanering: Stockholm, Sweden, 2010.

5. Bernstad, A.; La Cour Jansen, J.; Aspegren, H. Life cycle assessment of a household solid waste source separation programme: A Swedish case study. Waste Manage. Res. 2011, 29, 1027-1042.

6. Björklund, A.; Finnveden, G. Life cycle assessment of a national policy proposal—The case of a proposed waste incineration tax. Waste Manage. 2007, 27, 1046-1058.

7. European Environment Agency (EEA). The Road from Landfilling to Recycling: Common Destination, Different Routes; European Environment Agency: Copenhagen, Denmark, 2007; ISBN 978-92-9167-930-0.

8. Pires, A.; Martinho, G.; Chang, N-B. Solid waste management in European countries: A review of systems analysis techniques. J. Environ. Manage. 2011, 92, 1033-1050.

9. Gentil, E.; Clavreul, J.; Christensen, T.H. Global warming factor of municipal solid waste management in Europe. Waste Manage. Res. 2009, 27, 850-860.

10. EU. Directive 2008/98/EC of the European Parliament and of the Council of 19 November 2008 on Waste and Repealing Certain Directives; European Commission, Brussels, Belgium, 2008.

11. Swedish Government. Svenska miljömål-preciseringar av miljökvalitetsmålen och en första uppsättning etappmål (Swedish Environmental Objectives-Clarifications of the Envrionmental objectIves and a First Set of Milestones); Ds 2012:23; Regeringskansliet: Stockholm, Sweden, 2012.

12. Swedish Waste Management. Svensk avfallshantering 2010 (Swedish waste management 2010); Swedish Waste Management: Malmö, Sweden, 2011.

13. Ljunggren Söderman, M. Assessment of Policy Instruments for Waste Prevention; Presentation at the ISWA Beacon Conference on Waste Prevention and Recycling, Vienna, Austria, 2011; ISWA: Vienna, Austria, 2011.

14. Swedish EPA. Avfall i Sverige 2010 (Waste in Sweden 2010); Report 6520; Swedish EPA: Stockholm, Sweden, 2012.

15. Swedish EPA. Från avfallshantering till resurshushållning. Sveriges avfallsplan 2012-2017 (From Waste Management to Resource Management. Waste plan of Sweden 2012-2017); Swedish EPA: Stockholm, Sweden, 2012.

16. Von Borgstede, C.; Andersson, K. Environmental information-Explanatory factors for information behavior. Sustainability 2010, 2, 2785-2798.

17. Henriksson, G.; Åkesson, L.; Ewert, S. Uncertainty regarding waste handling in everyday life. Sustainability 2010, 2, 2799-2813.

18. Swedish District Heating Association, 2012. Available online: http://www.svenskfjarrvarme.se/ Statistik--Pris/Fjarrvarme/Energitillforsel/ (accessed on 14 November 2012).

19. Towards Sustainable Waste Management, 2013. Available online: http://www. hallbaravfallshantering.se (accessed on 21 February 2013).

20. Bisaillon, M.; Finnveden, G.; Noring, M.; Stenmarck, Å.; Sundberg, J.; Sundqvist, J.-O.; Tyskeng, S. Nya styrmedel inom avfallsområdet? (New Policy Measures for Waste 
Management?); Miljöstrategisk analys-fms, ISSN 1652-5442, TRITA-INFRA-FMS 2009:7; KTH Royal Institute of Technology: Stockholm, Sweden, 2009.

21. Finnveden, G.; Bisaillon, M.; Noring, M.; Stenmarck, Å; Sundberg, J.; Sundqvist, J.-O.; Tyskeng, S. Developing and evaluating new policy instruments for sustainable waste management. Int. J. Environ. Sust. Develop. 2012, 11, 19-31.

22. Dreborg, K.-H.; Tyskeng, S. Framtida förutsättningar för en hållbar avfallshanteringÖvergripande omvärldsscenarier samt referensscenario (Future conditions for a sustainable waste management-General environment scenarios and reference scenario); Miljöstrategisk analys-fms, TRITA-INFRA-FMS 2008:6; KTH Royal Institute of Technology: Stockholm, Sweden, 2008.

23. Sjöström, M.; Östblom, G. Future Waste Scenarios for Sweden Based on a CGE-model; Working Paper no. 109; National Institute of Economic Research: Stockholm, Sweden, 2009.

24. Östblom, G.; Ljunggren Söderman, M.; Sjöström, M. Analysing Future Waste Generation-Soft Linking a Model for Waste Management with a CGE-model for Sweden; Working paper no. 118; National Institute of Economic Research: Stockholm, Sweden, 2010.

25. Ljunggren Söderman, M.; Björklund, A.; Eriksson, O.; Forsfält, T.; Stenmarck, Å.; Sundqvist, J.-O. Policy Instruments for a More Sustainable Waste Management; Presentation at LCM 2011, Berlin, Germany, 2011. Available online: http://www.lcm2011.org (accessed on 21 February 2013)

26. Östblom, G.; Berg, C. The EMEC model: Version 2.0; Working Paper no. 96; National Institute of Economic Research: Stockholm, Sweden, 2006.

27. Forsfält, T. Samhällsekonomiska effekter av två styrmedel för minskade avfallsmängder (Socioeconomic impacts of two policy measures towards reduced waste amounts); Specialstudie nr 26; National Institute of Economic Research: Stockholm, Sweden, 2011.

28. Ljunggren, M. Modelling national solid waste management. Waste Manage. Res. 2000, 18, $525-537$.

29. Ljunggren Söderman, M. Ekonomisk analys av nya styrmedel för hanteringen av svenskt avfall (Economic Analysis of New Policy Measures for Management of Swedish Waste); Report B 2021; IVL Swedish Environmental Research Institute: Stockholm, Sweden, 2011.

30. Arushanyan, Y.; Björklund, A.; Eriksson, O.; Finnveden, G.; Ljunggren-Söderman, M.; Sundqvist, J.-O.; Stenmarck, Å. Environmental Assessment of Waste Policy Instruments in Sweden, 2013, in progress.

31. ISO. ISO 14040 International Standard. In Environmental Management-Life Cycle Assessment -Principles and Framework; International Organisation for Standardization: Geneva, Switzerland, 2006.

32. Clift, R.; Doig, A.; Finnveden, G. The Application of Life Cycle Assessment to Integrated Solid Waste management, Part I-Methodology; Process Safety and Environmental Protection, 2000, 78, 279-287.

33. Finnveden, G.; Hauschild, M.; Ekvall, T.; Guinée, J.; Heijungs, R.; Hellweg, S.; Koehler, A.; Pennington, D.; Suh, S. Recent developments in Life Cycle Assessment. J. Environ. Manage. 2009, 91, 1-21.

34. Pré. Simapro 7 Professional Version 7.3.2.; Pre Consultants: Amersfoort, The Netherlands, 2011. 
35. Goedkoop, M.; Heijungs, R.; Huijbregts, M.; De Scryver, A.; Sruijs, J.; van Zelm, R. ReCiPe 2008, Report 1: Characterization; Ministry of VROM: The Hague, The Netherlands, 2009.

36. Frischknecht, R.; Jungbluth, N.; Althaus, H.; Doka, G.; Dones, R.; Hellweg, S.; Hischier, R. Implementation of Life Cycle Impact Assessment Methods; Swiss Center for Life Cycle Inventories: Duebendorf, Switzerland, 2007.

37. Bösch, M.; Hellweg, S.; Huijbregts, M.; Frischknecht, R. Applying cumulative exergy demand (CExD) indicators to the ecoinvent database. Int. J. Life Cycle Ass. 2006, 12, 181-190.

38. Ekvall, T. Key methodological issues for life cycle inventory analysis of paper recycling. J. Clean. Prod. 1999, 7, 281-294.

39. Wene, C.-O. Exploring and Mapping: A Comparison of the IEA-MARKAL and CEC-EFOM Technical Energy System Models and the ANL Electric Utility Model; Technical report BNL52224; Brookhaven National Lab.: Upton, NY, USA, 1989.

40. Sahlin, J.; Ekvall, T.; Bisaillon, M.; Sundberg, J. Introduction of a waste incineration tax: Effects on the Swedish waste flows. Resour. Conserv. Recy. 2007, 51, 827-846.

41. Blomberg, J.; Söderholm, P. The economics of secondary aluminium supply: An econometric analysis based on European data. Resour. Conserv. Recy. 2009, 53, 455-463.

42. Ekvall, T.; Sahlin, J.; Sundberg, J. Effects of Policy Instruments on Waste Intensities; Report B1939; IVL Swedish Environmental Research Institute: Stockholm, Sweden, 2010.

43. Henriksson, G.; Åkesson, L.; Ewert, S. Uncertainty regarding waste handling in everyday life. Sustainability 2010, 2, 2799-2813.

44. Andersson, M.; von Borgstede, C.; Eriksson, O.; Guath, M.; Henriksson, G.; Sundqvist, J.-O.; Åkesson, L. Hållbar avfallshantering-utvärdering av styrmedel från psykologiskt och etnologiskt perspektiv (Sustainable Waste Management-Evaluation of Policy Measures from an Psychological and Ethnologivcal Perspective); TRITA-INFRA-FMS: 2011:5; KTH Royal Institute of Technology: Stockholm, Sweden, 2011.

45. Andersson, M.; Eriksson, O.; von Borgstede, C. The effects of environmental management systems on source separation in the work and home settings. Sustainability 2012, 4, 1292-1308.

46. Geertz, C. The Interpretation of Cultures; Basic Books: New York, NY, USA, 1973.

47. Gram-Hanssen, K. Practice Theory and the Green Energy Consumer. Presentation at ESA Conference 3-6 September 2007 in Glasgow, Research Network on the Sociology of Consumption, 2007; ESA: Paris, France, 2007.

48. Ekvall, T.; Sundqvist, J.-O.; Hemström, K.; Jensen, C. Stakeholder Analysis of Incineration Tax, Raw Material Tax, and Weight-based Waste Fee; Draft report; IVL Swedish Environmental Research Institute: Stockholm, Sweden, 2011.

49. Söderholm, P.; Ekvall, T. Material Markets in the Presence of Secondary and Primary Production: Important Interactions and Policy Impacts. 2012; Draft version.

50. Söderholm, P. Taxing Virgin Natural Resources: Lessons from Aggregates Taxation in Europe. Resour. Conserv. Recy. 2011, 55, 911-922.

51. Olofsson, M.; Sahlin, J.; Ekvall, T.; Sundberg, J. Driving forces for import of waste for energy recovery in Sweden. Waste Manage. Res. 2005, 23, 3-12. 
52. Bergek, A.; Jacobsson, S. Are tradable green certificates a cost-efficient policy driving technical change or a rent-generating machine? Lessons from Sweden 2003-2008. Energ. Policy 2010, 38, 1255-1271.

53. Swedish Waste Management. National Survey of Analyses of Composition of Household's Solid Waste; Report U 2011:4; Swedish Waste Management: Malmö, Sweden, 2011.

54. Massachusetts Department of Environment Protection. Massachusetts 2010-2020. Solid Waste Master Plan. Pathway to Zero Waste; Massachusetts Department of Environment Protection: Boston, MA, USA, 2010.

55. Gerlat, A. Mandatory Organics Recycling to Become Law in Vermont, 2012. Available online: http://waste360.com/state-and-local/mandatory-organics-recycling-become-law-vermont (accessed on 14 November 2012).

56. Metro Vancouver. Banned and Prohibited Materials, 2012. Available online: http://www.metrovancouver.org/services/solidwaste/disposal/Pages/bannedmaterials.aspx (accessed on 14 November 2012).

57. Ahlroth, S.; Finnveden, G. Ecovalue08-A new valuation set for environmental systems analysis tools. J. Clean. Prod. 2011, 19, 1994-2003.

58. Arushanyan, Y.; Finnveden, G. Ban on incineration, weighting gf.xlsx; Spread-sheet Data, 20120222; Stockholm, Sweden, 2012; Unpublished.

59. Nilsson, H. Förpacknings- och tidningsinsamlingen AB, Stockholm, Sweden. Personal communication, 13 December 2011.

60. Profu. Tillgång och efterfrågan på behandlingskapacitet för brännbart och övrigt organiskt avfall. Underlag till Sveriges nationella avfallsplan 2011-Del 1. (Supply and Demand for Treatment Capacity of Combustible and Other Organic Waste. Data for Sweden's National Waste Plan 2011-Part 1); Profu: Mölndal, Sweden, 1 April 2011.

61. Fischer, J. Massachusetts Department of Environment Protection, Boston, MA, USA, Personal Communication, 22 February 2012.

62. O'Doherty, R.; Bailey, I.; Colins, A. Regulatory failure via market evolution: The case of UK packaging recycling. Environ. Plann. C Govern. Pol. 2003, 21, 579-595.

63. Matsueda, N.; Nagase, Y. An economic analysis of the packaging waste recovery note system in the UK. Resour. Energy Econ. 2012, 34, 660-679.

64. Edjemo, T.; Söderholm, P. Steel Scrap Markets in Europe and the USA. Miner. Energ. 2008, 23, 57-73.

65. Weitzman, M. Prices vs. Quantities. Rev. Econ. Stud. 1974, 41, 447-491.

66. Björklund, A.; Finnveden, G. Life cycle assessment of a national policy proposal—The case of a proposed waste incineration tax. Waste Manage. 2007, 27, 1046-1058.

67. SOU. Skatt i retur (Tax in return); SOU 2009:12; Fritzes: Stockholm, Sweden, 2009.

68. Dahlén, L.; Lagerkvist, A. Pay as you throw: Strengths and weaknesses of weight-based billing in household waste collection systems. Waste Manage. 2010, 30, 23-31.

69. Hage, O.; Sandberg, K.; Söderholm, P.; Berglund, C. Household Plastic Waste Collection in Swedish Municipalities: A Spatial-Econometric Approach. In Proceedings of The 16th Annual Conference of the European Association of Environmental and Resource Economists (EAERE), Gothenburg, Sweden, 25-28 June, 2008; EAERE: Venice, Italy, 2008. 
70. Hedman, B.; Näslund, M.; Nilsson, C.; Marklund, S. Emissions of polychlorinated Dibenzodioxins and Dibenzofurans and Polychlorinated Biphenyls from uncontrolled burning of garden and domestic waste (Backyard Burning). Environ. Sci. Technol. 2005, 39, 8790-8796.

71. Schmidt, L.; Sjöström, J.; Palm, D.; Ekvall, T. Viktbaserad avfallstaxa-Vart tar avfallet vägen? (Weight-Based Waste Tariff-Where does the Waste Go?); Report B 2054; IVL Swedish Environmental Research Institute: Stockholm, Sweden, 2012.

72. Sterner, T.; Bartelings, H. Household waste management in a Swedish Municipality: Determinants of waste disposal, Recycling and composting. Environ. Resour. Econ. 1999, 13, 473-491.

73. Fullerton, D.; Kinnaman, T.C. Garbage, Recycling and Illicit Burning or Dumping. J. Environ. Econ. Manag. 1995, 29, 78-91.

74. Walls, M.; Palmer, K. Upstream pollution, Downstream waste disposal, And the design of comprehensive environmental policies. J. Environ. Econ. Manag. 2001, 41, 94-108.

75. Söderholm, P., Ed.; Environmental Policy and Household Behavior: Sustainability and Everyday Life; Earthscan: London, UK, 2010.

76. Thøgersen, J. Monetary incentives and environmental concern. Effects of a differentiated garbage fee. J. Consum. Policy 1994, 17. 407-443.

77. Kinnaman, T.C. Policy Watch: Examining the Justification for Residential Recycling. J. Econ. Perspec. 2006, 20, 219-232.

78. Swedish EPA. System för insamling av hushållsavfall i materialströmmar (System for collection of household waste in material streams); Report 5942; Swedish EPA: Stockholm, Sweden, 2009.

79. Palmer, K.; Sigman, H.A.; Walls, M. The Cost of Reducing Municipal Solid Waste. J. Environ. Econ. Manag. 1997, 33, 128-150.

80. Ljunggren Söderman, M.; Björklund, A. Konsumtion, produktion och framtida avfall-effekter på miljö och ekonomi (Consumption, Production and Future Waste-Effects on the Environment and Economy). Presentation at the conference Avfall i nytt fokus, Borås, Sweden, 2010. Available online: http://www.hallbaravfallshantering.se/ (accessed on 21 February 2013).

81. Brekke, K.A.; Kipperberg, G.; Nyborg, K. Social interaction in responsibility ascription: The case of household recycling. Land Econ. 2010, 86, 766-784.

82. Bruvoll, A.; Nyborg, K. The cold shiver of not giving enough: On the social cost of recycling campaigns. Land Econ. 2004, 80, 539-549.

83. Cela, E.; Kaneko, S. Determining the effectiveness of the Danish packaging tax policy: The case of paper and paperboard and packaging imports. Resour. Conserv. Recy. 2011, 55, 836-841.

84. Rouw, M.; Worrell, E. Evaluating the impacts of packaging policy in The Netherlands. Resour. Conserv. Recy. 2011, 55, 483-492.

85. Monomaivibool, V.; Vassanadumrongdee, S. Extended Producer Responsibility in Thailand. Prospects for Policies on Waste Electrical and Electronic Equipment. J. Ind. Ecol. 2011, 15, 185-205.

86. Mayers, K.; Peagam, R.; France, C.; Basson, L.; Clift, R. Redesigning the Camel: The European WEEE directive. J. Ind. Ecol. 2011, 15, 4-8.

87. Lindhqvist, T. Policies for waste batteries: Learning from experience. J. Ind. Ecol. 2010, 14, 537-540. 
88. Cleary, J. Life cycle assessments of wine and spirit packaging at the product and municipal scale: A Toronto, Canada case study. J. Clean. Prod. 2013, in press.

89. Gentil, E.; Gallo, D.; Christensen, T.H. Environmental evaluation of municipal waste prevention. Waste Manage. 2011, 31, 2371-2379.

90. Ljunggren Söderman, M.; Davidsson, H.; Jensen, C.; Palm, D.; Stenmarck, Å. Goda exempel på förebyggande av avfall från kommuner (Good Examples of Waste Prevention in Municipalities); Report U 2011:5; Swedish Waste Management: Malmö, Sweden, 2011.

91. Salhofer, S.; Obersteiner, G.; Schneider, F.; Lebersorger, S. Potential for the prevention of municipal solid waste. Waste Manage. 2008, 28, 245-259.

92. Nicolli, F.; Johnstone, N.; Söderholm, P. Resolving Failures in Recycling Markets: The Role of Technological Innovation. Environ. Econ. Policy Stud. 2012, 14, 261-288.

93. Watkins, G.; Husgafvel, R.; Pajunen, N.; Dahl, O.; Heiskanen, K. Overcoming institutional barriers in the development of novel process industry residue based symbiosis product-Case study at the EU level. Miner. Eng. 2013, 41, 31-40.

94. Fullerton, D.; Wu, W. Policies for Green Design. J. Environ. Econ. Manag. 1998, 25, 242-256.

95. Calcott, P.; Walls, M. Waste, Recycling, and 'Design for Environment': Roles for Markets and Policy Instruments. Resour. Energ. Econ. 2005, 27, 283-305.

96. Johansson, J.G.; Björklund, A.E. Reducing lifecycle environmental impact of waste electrical and electronic equipment recycling. J. Ind. Ecol. 2010, 14, 258-269.

97. Söderholm, P. Economic Instruments in Chemicals Policy: Past Experiences and Prospects for Future Use; TemaNord 2009:565; Nordic Council of Ministers: Copenhagen, Denmark, 2009.

98. Tyskeng, S.; Finnveden, G. Comparing energy use and environmental impacts of recycling and incineration. J. Environ. Eng. 2010, 136, 744-748.

99. Nakatani, J.; Fujii, M.; Moriguchi, Y.; Hirao, M. Life-cycle assessment of domestic and transboundary recycling of post-consumer PET bottles. Int. J. Life Cycle Ass. 2010, 15, 590-597.

100. Profu. Evaluating Waste Incineration as Treatment and Energy Recovery Method from an Environmental Point of View; Report on behalf of CEWEP (Confederation of European Wasteto-Energy Plants), Final Version, 13 May 2004; Profu: Mölndal, Stockholm, 2004.

101. Eriksson, O.; Finnveden, G. Plastic waste as a fuel- $-\mathrm{CO}_{2}$-neutral or not? Energ. Environ. Sci. 2009, 2, 907-914.

102. Damon, M.; Sterner, T. Policy Instruments for sustainable development at Rio +20 . J. Environ. Develop. 2012, 21, 143-151.

103. Henriksson, G.; Börjesson Rivera, M.; Åkesson, L. Environmental policy instruments seen as negotiations. In Negotiating Environmental Conflicts: Local communities, global policies (published within the series Kulturanthropologie Notizen, vol. 81); Goethe Universität: Frankfurt am Main, Germany, 2012.

104. Hajer, M.A. A Frame in the Fields: Policymaking and the Reinvention of Politics. In Deliberative Policy Analysis: Understanding Governance in the Network Society; Hajer, M.A., Wagenaar, H., Eds.; Cambridge University Press: Cambridge, UK, 2003; pp. 88-110.

105. Henriksson, G. What did the Trial Mean for Stockholmers? In Congestion Taxes in City Traffic: Lessons Learnt from the Stockholm Trial; Gullberg, A., Isaksson, K., Eds.; Nordic Academic Press: Lund, Sweden, 2009; pp. 235-294. 
106. Shove, E.; Walker, G. Governing transistions in the sustainability of everyday life. Res. Policy 2010, 39, 471-476.

107. Gulliver, P.H. Anthropological contributions to the study of negotiations. Negotiation J. 1988, 4, 247-255.

108. Worster, D. Nature's Economy. A History of Ecological Ideas, 2nd ed.; Cambridge University Press: Cambridge, UK, 1996.

109. Ostrom, E. Coping with tragedies of the commons. Annu. Rev. Polit. Sci. 1999, 2, 493-535.

(C) 2013 by the authors; licensee MDPI, Basel, Switzerland. This article is an open access article distributed under the terms and conditions of the Creative Commons Attribution license (http://creativecommons.org/licenses/by/3.0/). 